\title{
Os limites do reformismo bourbônico: a propósito da administração da justiça na América espanhola ${ }^{1}$
}

The limits of the Bourbon reformism.

The Administration of Justice in

Spanish America

\section{Carlos Garriga²}

Catedrático de Historia del Derecho na Universidad del País Vasco (UPV/

EHU - Espanha).

e-mail: carlos.garriga@ehu.es
Tradução de "Los límites del reformismo borbónico: a propósito de la administración de la justicia en Indias". In: PINTADO, Feliciano Barrios (coord.). Derecho y administración pública en las Indias hispánicas. Actas del XII Congreso Internacional de Historia del Derecho Indiano, (Cuenca, Universidad de Castilla-La Mancha, 2002), I, p.781-821, realizada por Waldomiro Lourenço da Silva Júnior.

2

Projeto de investigação HICOES V (DER2010-21728-C02-02). Grupo UFI 11/05 (UPV/EHU)

\section{Resumo}

0 presente ensaio reflete acerca das possibilidades de reformar a administração da justiça no século XVIII, com o objetivo de discutir alguns problemas relativos ao chamado reformismo bourbônico na América. A partir do marco jurídico e institucional estabelecido (justiça de juizes), examina-se a política judicial da Monarquia Católica em relação às Audiências americanas e as reações que provocou entre os criollos letrados, para ilustrar os limites que a ordem jurídica tradicional impunha à ação política da Coroa (reforma como restauração).

\section{Abstract}

This essay considers the possibilities of reforming the administration of justice in the 18th century, in order to address some problems related to the so-called Bourbon reformism in America. From the legal and institutional framework established (justice of judges), it discusses the judicial policy of the Catholic Monarchy with regard to the American Audiencias and the reactions it provoked among the creole lawyers, in order to show the limits imposed by the traditional legal order to the political action of the Crown (reform as restoration).

\section{Palavras-chave}

Reformismo bourbônico, administração da justiça, Audiências Reais, América Espanhola, justiça de juízes

\section{Keywords}

Bourbon reforms, administration of justice, Royal Courts of Justice, Spanish America, justice of judges 
Como não pretendo elaborar um estado da questão, que dou por conhecido, senão mais propriamente um ensaio de interpretação a partir de uma leitura crítica da historiografia, me limitarei às referências bibliográficas necessárias ao meu argumento. Uma revisão atualizada das últimas publicações sobre o "reformismo bourbônico" pode ser encontrada em: GUIMERÁ, Agustín (ed.). El reformismo borbónico. Una visión interdisciplinar. Madrid: Alianza, 1996. p.9-33.

4

Veja-se, simplesmente: ÁLVAREZ DE MIRANDA, Pedro. Proyectos y proyectistas en el siglo XVIII español. Boletín de la Real Academia Española, Tomo LXV, p.409-429, 1985, que retoma a bibliografia anterior.

5

0 caminho foi marcado por Miguel Artola há mais de 40 anos, descobrindo no Nuevo sistema de Campillo as chaves da política reformista de Carlos III: Campillo y las reformas de Carlos III. Revista de Indias, v.XII, n.50, p.685-714, 1952; sendo mais recentemente percorrido por Luis Navarro Garcia, que busca a explicação da política americana de Gálvez no Discurso que o ministro escreveu em sua juventude: La política americana de José de Gálvez según su "Discurso y reflexiones de un vasallo". Málaga: Algazara, 1998.

6

Cf., p.e.: PÉREZ HERRERO, Pedro. I principi politici del riformismo borbonico americano. Considerazione storiografiche. Rivista Storica Italiana, v.XCIX, n.3, p.696-717, 1987; Idem. Los comienzos de la política reformista americana de Carlos III. Cuadernos Hispanoamericanos. Los Complementarios, n.2, p.53-70, 1988; Idem. Reformismo borbónico y crecimiento económico en la Nueva España. In: GUIMERA, Agustín (ed.). El reformismo borbónico. Madrid: Alianza Editorial, Mapfre America, 1996. p.75-107, especialmente p.78-91.

7

Assim, em BRADING, David A. Mineros y comerciantes en el México Borbónico (1763-1810). México: FCE 1993. p.55-132; Idem. La España de los Borbones y su imperio americano. In: BETHELL, Leslie (ed.). Historia de América Latina. Vol.2. América Latina Colonial: Europa y América en los siglos XVI, XVII y XVIII. Barcelona: Crítica, 1990. p.85-126.

8

Cf. LYNCH, John. El siglo XVIII (Historia de España, XII). Edição original inglesa de 1989. Barcelona: Crítica, 1991. p.295-336; Idem. El reformismo borbónico e Hispanoamérica. In: GUIMERA, Agustín (ed.). Op. Cit., p.37-59.

9

Contrariamente a isto, e desde o ponto de vista da história econômica, veja-se a proposta (que substancialmente compartilho) de: DELGADO RIBAS, Josep Maria. América en la teoría y praxis política de José Moñino y Redondo, conde de Floridablanca, Hacienda Pública Española, 108-109, p.133-146, 1987.

10

Para este argumento deve consultar-se: ESCUDERO, José Antonio. Los orígenes del Consejo de Ministros en España. La Junta Suprema de Estado. 2 Vols. Madrid: Editora Nacional, 1979.
Adianto que não vou analisar as reformas do aparato de justiça indiano durante o século XVIII, senão que pretendo considerar, sempre e apenas com relação às Audiencias, a ideia mesma de reforma da justiça ou, mais propriamente, o seu alcance e as suas possibilidades de realização naquele período. 0 meu propósito é chamar atenção acerca de alguns problemas que entendo relevantes para a compreensão do chamado "reformismo bourbônico" no espaço institucional que acabo de delimitar, frequentemente não levados em consideração pela historiografia. Creio que se pode afirmar em termos gerais que o tópico em questão é abordado por uma chave exclusivamente política (e em certas ocasiões da política moderna), quase sempre, com preterição da vertente jurídica que lhe é mais própria. Este é o problema que quero considerar. ${ }^{3}$ Explico-me.

No século XVIII, floresce entre nós o proyectismo como gênero e o reformismo como prática. ${ }^{4}$ Uns projetam: especialmente a partir das décadas centrais proliferam textos de indole muito variada que argumentam e propõem remédios, em ocasiões escritos pelos ministros ou servidores do rei. Outros (ou quiçá os mesmos, neste último caso) reformam: como sabido, sobretudo sob Carlos III, ensaiaram-se algumas mudanças institucionais de certo vulto. Naturalmente, a tentação de se estabelecer um nexo causal entre ambos os fenômenos é muito grande e frequentemente vence as barreiras que devem separar o historiador do tempo que estuda. Mesmo correndo o risco de simplificar e salvo algumas exceções que mencionarei, é consenso afirmar que os reis Bourbons seriam portadores de todo um programa reformista, cujas linhas mestras teriam sido definidas por um seleto grupo de ministros ilustrados, tendo sido posto em prática, com diferentes niveis de sucesso, por aqueles que governaram durante a segunda metade do século, com destaque para José de Gálvez..$^{5} 0$ modelo historiográfico coletivamente construido durante as últimas décadas para explicar o governo das Índias se nutre desta ideia, e gira sobre três eixos básicos, tendo servido como outros tantos polos de atração para os historiadores: a) o programa, que se tentou definir por distintas vias, mas sempre com o propósito de se descobrir a verdadeira intencionalidade de seus artífices; b) a execução do programa, centrado principalmente no impacto que a colocação em prática das ideias previamente alumbradas teve nas Índias ${ }^{6}$; c) a avaliação de suas consequências, finalmente contempladas de modo indefectivel desde a atalaia da independência, como o grande fenômeno que encerra este ciclo histórico. Dito de um modo enfático: o reformismo bourbônico teria sido um curto-circuito no devir histórico hispano-americano, que terminaria por inflamar as chamas da independência.

David A. Brading, em particular, qualificou o conjunto de mudanças introduzido pelos Bourbons no governo das Índias como uma autêntica "revolução no governo", elevando-a à chave explicativa da última etapa colonial. ${ }^{7}$ E não é muito diferente o ponto de vista de John Lynch, para quem as reformas bourbônicas representaram uma nova colonização da América, que inaugurou uma etapa de sua história, o "segundo império", 
Além da obra de BERNARD, Gildas. Le Secrétariat d'État et le Conseil espagnol des Indes (17001808). Genève-Paris: Librairie Droz, 1972, veja-se BURKHOLDER, Mark A. The Council of the Indies in the Late Eighteenth Century: A New Perspective. Hispanic American Historical Review, v.56, n.3, p.404-423, 1976, para a sua renovada importância, especialmente a partir de 1773. Para as Juntas, e especialmente sobre a Suprema de Estado com relação à América: BARBIER, Jacques A. The Culmination of the Bourbon Reforms, 1787-1792. Hispanic American Historical Review, v.57, n.1, p.51-68, 1977

12

Algo deve significar que o melhor modo de coordenar institucionalmente a ação de governo fosse a acumulação pessoal de ofícios: como é sabido, Gálvez, além de Secretario, foi nomeado presidente do Consejo de Indias em 1776 (BERNARD, Gildas. Op. Cit., p.53). Não é necessário recordar que este adotava suas decisões por maioria e, por conseguinte, não cabe identificar seus acordos com a opinião de algum de seus membros. 0 significado do Secretario na política americana tem sido marcado pela obra de PRIESTLEY, Herbert Ingram. José de Gálvez, Visitor-General of New Spain (1765-1771). Berkeley: University of California Press, 1916, repr. Philadelphia: Porcupine Press, 1980. Para situar melhor sua figura (e a de seu historiador), deve consultar-se SALVUCCI, Linda K. Costumbres viejas, hombres nuevos: José de Gálvez y la burocracia fiscal novohispana (1754-1800). Historia Mexicana, v.33, n.2, p.224-264, 1983.

13

Parece-me muito ilustrativo para isto o trabalho de KUETHE Allan J.; BLAISDELL, Lowell. French Influence and the Origins of the Bourbon Colonial Reorganization. Hispanic American Historical Review, v.71, n.3, p.579-607, 1991, que também destaca o papel de Esquilache e situa em seus justos termos o significado de Gálvez (esp. p.595-596).

14

Veja-se agora, simplesmente, o pioneiro ensaio de PHELAN, John Leddy. Authority and Flexibility in the Spanish Imperial Bureaucracy. Administrative Sciences Quaterly, n.5, p.47-65, 1960; e a revisão recentemente levada a cabo por PIETSCHMANN, Horst. Corrupción en las Indias españolas: revisión de un debate en la historiografía sobre Hispanoamérica colonial. In: JIMÉNEZ, Manuel González et al. Instituciones y corrupción en la historia. Universidad de Valladolid: 1998, p.31-52.

15

Para o argumento, remeto ao meu: El Corregidor en Cataluña. (Una lectura de la obra de Josep M. Gay Escoda). Initium. Revista Catalana d'História del Dret, n.3, p.531-583, 1998, esp. p.558-559 y p.575-577; LLOMBART, Vicent. La política económica de Carlos III. ¿Fiscalismo, cosmética o estímulo al crecimiento? Revista de Historia Económica, año XII, n.1, p.11-39, 1994, traz algunas indicações interessantes.

16

Cf. CLAVERO, Bartolomé. Antidora. Antropología católica de la economía moderna. Milano: Giuffrè, 1991; assim como o inicio de seu Beati dictum: motivo último da ebulição de sentimentos de identidade que levou à independência. ${ }^{8} 0$ discurso historiográfico demarca, portanto, um espaço de descontinuidade, aberto pelas reformas dos Bourbons e no qual - se se admite esta simplificação - devem ser alinhavados os fios que entrelazam o fenômeno inicial com o evento final. Embora esta perspectiva sem dúvida apresente muitos pontos de interesse, deixa na penumbra (não necessariamente ignora) a evidente continuidade que dá sentido ao Antigo Regime e menospreza (nem sempre omite) o tratamento dos meios de reforma disponíveis e a consideração dos instrumentos efetivamente colocados à disposição para alcançá-los. Ao fim e ao cabo, de acordo com a abordagem assinalada, o problema historiográfico se estabelece prioritariamente em torno da discussão sobre os fins (que se pretendia) e os resultados (que se fez e, sobretudo, com que consequências) da política reformista. Nessa tarefa, as chaves interpretativas são dadas em boa medida pelo enfoque adotado: a Coroa elaborou uma estratégia de domínio, que aplicou com coerência para alcançar os objetivos políticos perseguidos, concebidos assim como a causa determinante das medidas de governo efetivamente adotadas. ${ }^{9}$ Naturalmente, quando o historiador cultiva esse campo semântico, os frutos que obtém levam nomes como controle, centralização, política antiamericana... Pergunto-me se não responderão a uma pré-compreensão da realidade histórica (não importando agora o que entendemos por esta) derivada mais da consideração dos fins reformistas declarados do que da análise dos meios institucionais empregados. 0 discurso normativo, e menos a linguagem dos projetos, nem sempre coincidem com as possibilidades dos reformadores e quase nunca se corresponde com suas realizações. Com efeito, se não estou equivocado, alguns desses qualificativos dificilmente poderiam ser utilizados caso fossem levados em consideração os instrumentos de governo disponíveis e se prestasse maior atenção às concepções juridicas que Ihes davam sentido.

Este é o terreno sobre o qual se moverão as considerações que se seguem, animadas pelo propósito de problematizar algumas das certezas assinaladas. Com tal fim, começarei por fazer algumas observações elementares (que entendo necessárias) sobre o governo das Índias (I), para depois tratar de determinar do que estamos falando quando falamos da administração da justiça (II), tarefa que considero imprescindível se se quer compreender as medidas adotadas para a reforma das Audiencias durante o século XVIII em seu próprio contexto (III), que nem sempre coincide com o fabricado pela historiografia (IV); e terminarei, de volta ao princípio, com uma breve consideração sobre as possibilidades e os limites do "reformismo bourbônico" (V).

\section{(I)}

Sem dúvida, a consideração dos projetos de reforma - quaisquer que sejam; inclusive aqueles que podemos considerar programas de governo - pode e deve proporcionar o contexto das decisões tomadas, esclare- 
derecho de linaje, economía de familia y cultura de orden. Anuario de Historia del Derecho Español, N.LXIII-LXIV, p.7-148, 1993-1994; Idem. La monarquía, el derecho y la justicia. In: MARTíNEZ RUIZ, Enrique; DE PAZZIS PI, Magdalena (coords.). Instituciones de la España Moderna. 1. Las jurisdicciones. Madrid: Actas, 1996. p.15-38, especialmente, o trecho final.

17

Veja-se agora, por todos, MAYALI, Laurent. Entre idéal de justice et faiblesse humaine: le juge prévaricateur en droit savant". In: Justice et justiciables. Mélanges Henri Vidal (=Recueil de mémoires et travaux publié par la Société d'Histoire du Droit et des Institutions des anciens Pays de Droit écrit, fasc. XVI), Faculté de Droit, d'Économie et de Gestion de Montpellier, 1994. p.91-103. Para um resumo atualizado do argumento, é útil: BRUNDAGE, James A. Medieval Canon Law. London-New York: Longman, 1995. p.120-174.

18

Cf. LEFĖBVRE, Charles. Juges et savants en Europe (13e-16e s.). L'apport des juristes savants au développement de l'organisation judiciaire. Ephemerides luris Canonici, v.XXII, p.76-202, 1966 y v.XXIII, p.9-61, 1967.

19

Tomo a expressão de CASTILLO DE BOVADILLA Jerónimo. Política para corregidores y señores de vassallos, en tiempo de paz, y de guerra. Y para Juezes Eclesiasticos y Seglares y de Sacas, Aduanas, y de Residencias, y sus Oficiales: y para Regidores, y Abogados, y del valor de los Corregimientos, y Goviernos Realengos, y de las Ordenes. Amberes: En casa de luan Bautista Verdussen, 1704. Ed. facs., con "Estudio preliminar" de Benjamín González Alonso. Madrid: Instituto de Estudios de Administración Local, 1978, lib.l, cap.II.

20

Para a sua aplicação sobre o aparato instituciona do Antiguo Régimen, cf.: HESPANHA, António Manuel. Visperas de Leviatán. Instituciones y poder político (Portugal, siglo XVII). Trad. de F. J. Bouza Alvarez. Madrid: Taurus, 1989.

21

Para o argumento: VIEHWEG, Theodor. Tópica y jurisprudencia (1963). Trad. de L. Díez-Picazo. Madrid: Taurus, 1986; e, para o que importa aqui, a obra fundamental de TAU ANZOÁTEGUI, Victor. Casusimo y sistema. Indagación histórica sobre el espiritu del Derecho Indiano. Buenos Aires: Instituto de Investigaciones de Historia del Derecho, 1992.

22

Não é demais dizer que são fruto de minha leitura da doutrina, das disposições régias e demais documentos judiciais, assim que me parece ocioso citar agora suas fontes pormenorizadamente: as considerei detidamente em meu trabalho inédito "Sobre el gobierno de la justicia en Indias (siglos XVI-XVII)" [agora publicado na Revista de Historia del Derecho, n.24, Buenos Aires, 2006, p.67-160]. Além disso, e com caráter geral, basta aqui remeter à Recopilacion de Leyes de los Reynos de las Indias, mandadas imprimir y publicar por la Magestad Católica del Rey Don Cárlos II Nuestro señor [1681]. Madrid: Impr. Viuda de Ibarra, 1791 (Ed. facs., 3 Vols., Madrid, BOE, 1998), lib.2, tít.16, cendo-se em que medida revelam mudanças nas concepções tradicionais (adjetivadas de modo correspondente a cada caso: políticas, juridicas, econômicas), mas buscar neles a política da Coroa exigiria explicar como as ideias se metabolizaram em práticas de governo. A pergunta-chave a este respeito é: como se governa?

Com efeito, já que a conexão entre as ideias projetadas (fossem quais fossem) e as mudanças institucionais não é óbvia, qualquer tentativa de compreender o reformismo bourbônico exige pelo menos a consideração de como se passou - no caso - das primeiras para as segundas. Como as decisões foram adotadas e através de quais mecanismos se tratou de colocá-las em prática? Entendendo assim, isso que chamamos governo é nas sociedades do Antigo Regime um processo altamente aleatório, porque possivelmente dependerá mais das circunstâncias próprias da constituição tradicional da monarquia do que das ideias ou da vontade de impôr-las. Entre tais circunstâncias merecem agora uma especial consideração as que rodeavam imediatamente o rei (ii) e aquelas que condicionavam a atuação de seu aparato institucional, tanto no centro (i) como nos territórios americanos (iii). 0 farei de forma simple e breve, a partir de outras tantas proposições que entendo verdades sabidas.

(i) A complexidade do processo de preparação e tomada de decisões então dificultava sobremaneira a conversão dos planos ou projetos em disposições normativas aptas, sob a forma que fosse, à aplicação. Sem contar outras instâncias que com seus informes e representações eram igualmente relevantes (como a dos virreyes), recorde-se que a labirintica estrutura do aparato central da Monarquia dificultava a priori a unidade de critério de sua política, a política da Coroa. ${ }^{10}$ Basta conjugar os três elementos principais: o Secretario de Estado y del Despacho; o Consejo de Indias, que foi revitalizado no tempo de Carlos III, embora tenha sempre ocupado um espaço próprio tão decisivo como o da administração da justiça (que, não custa lembrar, incidia diretamente sobre o governo daqueles territórios); e as Juntas que, formadas por um ou outro motivo, foram bastante numerosas e tiveram por vezes um papel importante. ${ }^{11} 0$ delicado jogo de equilibrio e as constantes interferências mútuas são bem conhecidos, mas nem sempre é levado em consideração para o efeito de que se trata: parece muito arriscasdo supor, em qualquer caso, que nestas condições toda a política americana pudesse ser dominada - como por vezes se disse - por um só homem (ainda que este fosse o todo-poderoso Gávez). ${ }^{12}$ Dadas as circunstâncias, tratar-se-ia bem mais de uma obra coletiva, fruto da integração e do compromisso, da negociação e do pacto entre diferentes posições; não foi, em suma, projetada de uma vez e, por isso, não é de se estranhar que frequentemente nos apareça como incoerente.

(ii) 0 caráter contraditório que por vezes parece ter a política régia aconselha não subestimar os fatores que podem influenciar a vontade do rei: não é ocioso insistir no peso literalmente decisivo que a própria consciência pode chegar a ter em sociedades não secularizadas, mas tampouco 
especialmente; e a SOLÓRZANO Y PEREYRA, Juan. Política indiana compuesta por el Señor Don [...], corregida, e ilustrada con notas por el Licenciado Don Francisco Ramiro de Valenzuela [...]. Madrid: 1736-1739 (ed. facs., con "Estudio preliminar" de Miguel Ángel Ochoa Brun. Madrid: BAE, 1972), 5 vols., maxime, lib. V, caps. III y cap.VIII-XI.

23

Pelas razões que se verão, quis citar o texto romano (D. 1,1,10,1) pela obra de MARTÍNEZ, Manuel Silvestre. Librería de jueces, utilísima y universal para Abogados, Alcaldes Mayores y Ordinarios, Corregidores é Intendentes, Jueces de Residencia y de Visita de Escribanos de toda España, Receptores de Castilla y Aragon, Regidores, Juntas de Proprios, Contribucion y Pósitos, Personeros, Diputados del Comun y demas Individuos de Tribunales Ordinarios: añadida, é ilustrada con mas de dos mil Leyes Reales, que autorizan su Doctrina. Tomo I [...]. Séptima impresión. Madrid: Imprenta de Don Benito Cano, 1791, cap.I, §I, 1, que seguidamente a adapta à Real Derecho Español nestes termos: "una virtud jurisdiccional con que se gobierna el mundo, $y$ se mantienen las cosas en el estado que prefine la Ley, con la que el Juez debe dar lo que por su legítimo derecho á cada uno pertenece" (p. 2).

24

A distinção entre ambas as pessoas foi nitidamente marcada por Santo Tomás de Aquino: "...iudicare pertinet ad iudicem secundum quod fungitur publica potestate. Et ideo informari debet in iudicando non secundum id quod ipse novit tanquam privata persona, sed secundum id quod sibi innotescit tanquam personae publicae" (Summa Theologica, 2-2, q.67, a. 3, edição da Biblioteca de Autores Cristianos, Tomo III. Madrid: Editorial Católica, 1963. p.434-435). É muito interessante para isto a análise da obra primeira de MATIENZO, Juan de. Dialogvs relatoris et advocati Pinciani senatus. In quo varia hinc inde proponuntur \& longe controuertuntur ad renunciatorum, aduocatorum, \& iudicum munera: eorumque dignitatem \& eminentiam spectantia, eorumdemque ad electionem probe faciendam plurima aduertuntur. Pinciae: Excudebat Sebastianus Martinez, 1558, maxime "Tertia pars", f.42r-259r), levada a cabo por VALLEJO, Jesús. Acerca del fruto del árbol de los jueces. Escenarios de la justicia en la cultura del ius commune. Anuario de la Facultad de Derecho de la Universidad Autónoma de Madrid, n.2, p.19-46, 1998.

25

SOLÓRZANO Y PEREYRA, Juan. Op. Cit., lib.V, cap. VIII, n.42: "al [magistrado] que vota no le toca mirar lo que ha de salir resuelto por la mayor parte, sino lo que él, en Dios, en su conciencia y prudencia debe votar y aconsejar, informado de buena y desapasionada razón su dictamen" (p. 131). Argumento que desenvolve em seu "Papel politico, con lugares de buenas letras, sobre la variedad de los dictamenes de los hombres, asi en el juzgar, como en el discurrir, a cerca de qualquier cosa". In: Obras varias posthumas del Doctor Don Juan de Solorzano Pereyra, [...]. Contienen una recopilacion de diversos Tratados, Memoriales, Papeles eruditos, y algunos Escritos en causas Fiscales [...] Corregidas y enmendadas en esta edicion por el Licenc.do D. Francisco Maria Vallarna, [...]. Madrid: Imprenta Real de la Gazeta, 1776. p.201-208. cabe minimizar a importância da Corte, se por tal entendemos o conjunto de personagens - políticos, em sentido lato - que rodeiam imediatamente o monarca e influem em suas decisões. ${ }^{13} \mathrm{~A}$ existência de uma única instância decisória suprema (admita-se o pleonasmo) não é a priori garantia de coerência política: a rigor, recorrentemente, não há uma, senão várias políticas igualmente régias, porque dependem igualmente da sua vontade, que deste modo se mostra a nós como literalmente fragmentada. Ao meu propósito imediato, basta propor uma cautela: nas condições assinaladas, a política régia não deve ser pressuposta como coerente, mas antes tida como gravemente ameaçada por contradições (as quais qualquer um pode apreciar em meio ao conjunto de disposições abertamente incompativeis de um mesmo rei). E é que, provavelmente, à diferença do que parecem crer alguns historiadores de hoje, ninguém nunca pensou que todas elas se cumprissem por completo.

(iii) Está claro que não se pode supor desavisadamente que as disposições régias determinavam a atuação do aparato institucional indiano, munido como estava de múltiplos recursos para obedecê-las, mas não cumpri-las (e não me refiro somente ao com este nome, senão a todos quantos meios serviam no universo conceitual do ius commune para moderar o rigor do direito). 0 problema das relações entre criação e cumprimento do direito característico das sociedades do Antigo Regime deveria ter aí uma importância capital, como desde um ponto de vista sociológico costumam destacar aqueles que tratam da corrupção burocrática nas Índias ${ }^{14}$. A delimitação nítida entre uma e outro de modo algum pode ser sustentada: como é sabido, ainda que nem sempre se tome em consideração, diversos mecanismos levavam de facto a completar - se não a controlar - a criação do direito durante o trâmite de seu cumprimento e, o que é mais, muitas vezes aquela consistia simplesmente em se estabelecer um canal para a adoção de decisões por parte das autoridades periféricas (que obviamente deviam atuar com um elevado grau de autonomia) ${ }^{15}$. Não é surpreendente, portanto, que com frequência os efeitos da política régia escapassem de antemão à decisão da Coroa e constitutivamente variassem de um distrito a outro. Destarte, para conhecer não só o alcance, mas o conteúdo mesmo das reformas é imprescindivel estudar o funcionamento e a atuação do aparato institucional indiano.

Importa-me muito sublinhar, dado o conteúdo destas páginas e a tendência contrária comumente observada pela historiografia das Audiencias, que esta consideração não deve levar à tomar por inútil o material jurídico, incluidas desde logo as disposições reais. Ao contrário, tenho para mim que a análise do discurso jurídico (normativo e jurisprudencial) é a única maneira de descobrir e compreender os critérios que governaram a justiça, isto é, as concepções que inspiraram a construção e as pautas que regeram o funcionamento do aparato judicial ao longo de todo o Antigo Regime. 
Que particularizava assim: "la conservacion de nuestra Santa Religion en su acendrada pureza, y aumento, y el bien y alivio de mis vasallos, la recta administracion de la justicia, la estirpacion de los vicios, y exáltacion de las virtudes", en el RD 10.II.1715, para prevenir ao Consejo de Indias, "atendiendo por lo consiguiente la seguridad de mi conciencia, que es inseparable de esto", que "replique a mis resoluciones, siempre que juzgare (por no haberlas yo tomado con entero conocimiento) contravienen a cualquiera cosa que sea, protestando delante de Dios, no ser mi animo emplear la autoridad que ha sido servido depositar en mi, sino para el fin que me la ha concedido, y que yo descargo delante de su divina Magestad sobre mis ministros" (apud MATRAYA Y RICCl, Juan Joseph. Catálogo cronológico de Pragmáticas, Cédulas, Decretos, Ordenes y Resoluciones Reales generales emanados después de la Recopilación de las Leyes de Indias (1819). Adv. prelim. de José Maria Mariluz Urquijo. Buenos Aires: Instituto de Investigaciones de Historia del Derecho, 1978, n.397. Veja-se também, p.e., a RC 31.I.1726, publicada em: RUIZ GUIÑAZÚ, Enrique. La magistratura indiana. Facultad de Derecho y Ciencias Sociales de la Universidad de Buenos Aires, 1916, p.357-358.

27

Remeto para tudo isto a GARRIGA, Carlos. La Audiencia y las Chancillerías castellanas (1375-1525). Historia política, régimen jurídico y práctica institucional. Madrid: Centro de Estudios Constitucionales, 1994; GARRIGA, Carlos; LORENTE, Marta. El juez y la ley: la motivación de las sentencias (Castilla, 1489-España, 1855). Anuario de la Facultad de Derecho de la Universidad Autónoma de Madrid, n.1, p.97-142, 1997, esp. p.101-114.

28

Para sua consideração nas Índias, é fundamental: CARRASCO DEL SAZ, Francisco. Tractatus de recusationibus, en su Interpretatio ad aliqvas leges recopilationis regni Castellae; explicataeque quaestiones plures, antea non ita discussae, in praxi frequentes iudicibus quibuscumque nec non causidicis, \& in Scholis vtiles, etiam Theologiae Sacrae professoribus, \& confesariis. Hispali, apud Hieronimvm a Contreras, 1620, cap.IX, ff.111r150v. Cf. GARRIGA, Carlos. La recusación judicial: del Derecho indiano al Derecho mexicano. In: La supervivencia del derecho español en Hispanoamérica durante la época independiente. México: Universidad Nacional Autónoma de México, 1998. p.203-239. As Ordenanzas aludidas foram publicadas por SÁNCHEZ-ARCILLA BERNAL, José. Las Ordenanzas de las Audiencias de Indias (1511-1821). Madrid: Dykinson, 1992.

29

Informe general sobre la visita, 20.X.1785, apud ESCOBEDO MANSILLA, Ronald. La visita general durante el reinado de Carlos III. Estudio comparativo. Revista Chilena de Historia del Derecho, n.11, p.315-327, 1985, especialmente, p.323.

30

MARTÍNEZ, Manuel Silvestre. Op. Cit., Tomo III. Madrid: Imprenta de Don Benito Cano, 1791, cap.I, p.1-68; para as edições, ver: GARCÍA GALLO, Alfonso. Metodología de la historia del
Do que falamos quando falamos da administração da justiça? Ao menos de uma certa ideia de justiça e de suas condições de realização, temas favoritos da Escolástica, que adquiriram em nossa Idade Moderna um desenvolvimento espetacular nos tratados de iustitia et iure, então sede de uma elaboradíssima teoria da justiça. Sem dúvida, a sua consideração seria de suma importância para a compreensão do aparato judicial castelhano (que é o mesmo que dizer indiano) dos séculos modernos. ${ }^{16}{ }^{6}$ Todavia, este não é o meu propósito aqui. Como acabo de insinuar, refiro-me agora, mais simplesmente, ao conjunto de ideias e crenças acerca da justiça e de sua realização que inspiram e explicam a articulação do aparato institucional da Monarquia, tal como aparecem em suas disposições e podem entreverse nas obras dos juristas, ainda que nem sempre se encontrem argumentativamente explicitadas. No tocante aos efeitos que aqui interessam, parece claro que a sua primeira formulação jurídica deve-se aos canonistas, seguramente vinculada à necessidade de substituição do mágico processo alto-medieval por um ordo iudiciario mais adequado às condições do tempo histórico que se descortinava. ${ }^{17}$ Como é sabido, a obra dos pontífices e canonistas do Duzentos foi decisiva neste terreno, e como tal seria assumida tanto pelos reis como pelo conjunto da doutrina jurídica baixo-medieval e moderna na hora de configurar o ofício de juiz e o caráter do juizo ${ }^{18}$ : a justiça judicial, em suma. ${ }^{19}$

Afinal de contas - voltemos ao princípio -, o aparato judicial não era mais que uma tradução institucional das concepções acerca da justiça e de sua realização, em boa medida compartilhadas pelo pensamento católico baixo-medieval e moderno, e adotadas pela doutrina política e jurídica do ius commune como base e como meta para sua prática. Como tal conjunto de ideias ou crenças compartilhadas e nem sempre explicitadas, pode ser considerado o paradigma da justiça, que amiúde aflora nas leis reais e nas obras doutrinais em forma de tópicos ou lugares comuns da argumentação, que ininterruptamente são assumidos no processo de aprendizagem e repetidos no de criação ao longo dos séculos que integram o chamado Antigo Regime.

De fato, ao conjunto que todas estas noções formam encaixa bem creio eu - o nome de paradigma, que, justamente em razão de sua utilidade, passou a formar parte do patrimônio comum da sociologia do conhecimento. ${ }^{20}$ Esta noção tem três vantagens principais para nossos efeitos:

a) Em primeiro lugar, destaca a importância que cabe ao processo de aprendizagem na reprodução do discurso sobre a justiça e sua realização, algo que não poderia se ajustar melhor a uma cultura eminentemente textual como a do ius commune, edificada sobre a autoridade de escritos quase sagrados, lidos e entendidos conforme a tradição.

b) Responde, ademais, à forma como a teoria da justiça comumente aparece nas obras dos juristas modernos e se manifesta nas disposições normativas, a saber, condensada em um conjunto de tópicos, naquelas 
Derecho indiano. Santiago de Chile: Editorial Jurídica de Chile, 1970. p.88. Havia sido fiscal de Santa Fé e, no momento da publicação, era oidor subdelegado da Audiencia de Guadalajara.

31

A expressão é de PHELAN, John Leddy. The Kingdom of Quito in the Seventeenth century. Bureaucratic Politics in the Spanish Empire. University of Wisconsin Press, 1967. p.153-176.

32

Sirva de exemplo, entre outros muitos, 0 comentário de LEBRÓN a Revista de Indias, 2.16, p.55-56: "Están derogadas por la costumbre, porque muchos Señores las tienen; si es por Cédula particular no se sabe: como tampoco alcanzo si valdrá esta costumbre contra la ley, contra las Cédulas que mandan se observen las Leyes y contra el juramento que dan de guardarlas. Si algún Sr. Ministro tuviere escrúpulo, estudiará el punto;....". Apud GARCIA GALLO, Concepción. José Lebrón y Cuervo. Notas a la Recopilación de Leyes de Indias. Estudio, edición e indices. Anuario de Historia del Derecho Español, n.XL, p.349-537, 1970, especialmente $p .422$.

33

Para o primeiro, cf.: PRODI, Paolo. // sacramento del potere. II giuramento politico nella storia costituzionale dell'Occidente. Bologna:,

II Mulino, 1992, esp. cap.V; argumento aplicado às Índias por D'ESPOSITO, Francesco. Encomienda, giuramento e strategie di controllo: il disciplinamento del funzionario nel Nuovo Mondo (secolo XVI)., In: Nestore Pirillo, a cura di, I/ vincolo del giuramento e il tribunale de la coscienza. Bologna: II Mulino, 1997. p.213-241.

34

Para o argumento, vide HESPANHA, António Manuel. Op. Cit.,p.26-27, p.132, p.229, p.414-435. 35

Cf. GARRIGA, Carlos. La expansión de la visita castellana a Indias: presupuestos, alcance y significado. XI Congreso del Instituto Internacional de Historia del Derecho Indiano. Buenos Aires, 4 al 9 de septiembre de 1995. Actas y estudios, III. Buenos Aires: Instituto de Investigaciones de Historia del Derecho, 1997. p.51-79.

36

Sobre a cronologia (1706-1711, 1740-1750), circunstâncias e modalidades de venda, veja-se: BURKHOLDER, Mark A.; CHANDLER, Dewitt S. Creole Appointments and the Sale of Audiencia Positions in the Spanish Empire under the Early Bourbons, 1701-1750. Journal of Latin American Studies, n.4, p.187-206, 1972; assim como o seu exaustivo estudo: De la impotencia a la autoridad. La Corona española y las Audiencias en América, 1687-1808. Trad. de R. Gómez Ciriza. México: FCE, 1984. p.33-118 (e os quadros correspondentes); a completar com seu Biographical Dictionary of Audiencia Ministers in the Americas, 1687-1821. Wesport-Connecticut, 1982. Com caráter geral, ver: NAVARRO GARCÍA, Luis. Los oficios vendibles en Nueva España durante la Guerra de Sucesión. Anuario de Estudios Americanos, v.XXXII, p.133-154, 1975; Fernando MURO ROMERO. El beneficio de oficios públicos con jurisdicción en Indias. Notas sobre sus orígenes. In: V Congreso del Instituto Internacional de Historia del derecho frequentemente ilustrados com uma torrente de exemplos históricos acerca da justiça, do juiz e de seu comportamento, das obrigações e das proibições que comporta o seu exercício,... que, longe de ser uma impostação teórica, são como tais efetivamente operativos no desenvolvimento de uma argumentação que busca a resolução de casos. ${ }^{21}$

Não tenho oportunidade de dedicar-me aqui a rebuscar e ordenar os referidos tópicos, mas como alguns deles são particularmente relevantes para o objeto destas páginas (ao menos como pano de fundo), bom será que os mencione agora, não sem antes pedir a indulgência do leitor para a forma simples e apodítica pela qual me vejo obrigado a fazê-lo22: (i) a noção de justiça mais operacional no campo judicial, base e fundamento da elaboração doutrinal durante séculos, encontra-se no início do Digesto, onde é concebida como a constante e perpétua vontade de dar a cada um o que é seu${ }^{23}$, que corresponde à justiça comutativa da Escolástica, também chamada judicial por alguns juristas, a qual pressupõe a igualdade das partes e sua realização exige, portanto, que o juiz esteja livre de toda paixão (amor, ódio, temor, cobiça), isto é, que atue como pessoa pública, alheio às inclinações naturais das pessoas privadas, em busca da verdade ${ }^{24}$; (ii) a verdade da justiça se obtém em cada caso por consenso, porque a variedade natural das opiniões entre os homens impede que se possa alcançar algo além de um resultado probabilista e determina, ao final, que a justiça seja fruto da concorrência de opiniões ou pareceres livres (i.e., sem paixão) dos magistrados, que são quem têm autoridade pública para defini-la (iurisdictio) ${ }^{25}$; (iii) todos eles estão obrigados por consciência, mediante juramento, a administrar a justiça (a julgar sem paixão), arriscam ao fazê-lo a salvação de sua alma imortal, e obviamente devem responder pela injustiça (redde rationem villicationis tuae [Lucas, 16], dizia a passagem do Evangelho constantemente invocada para esta finalidade), a quem tem, em virtude de seu ofício (isto é, de sua função na comunidade política), a responsabilidade da justiça perante Deus. A garantia última da justiça está, por isso, na consciência do rei, que desempenha o seu ofício organizando o governo da justiça (isto é, instituindo um aparato apto para a administração da justiça em seu nome) e implementando uma política judicial constantemente vigilante sobre os seus ministros, atento sempre ao clamor de seus súditos e pronto a desagravá-los, tal como prescreve a passagem bíblica descendam et videbo [Gênesis, 18], que é a comumente utilizada para fundamentar esta atividade do rei, premiando os bons e castigando os maus para descargo de sua consciência. Afinal de contas, estes são, como recordava Felipe V, "los motivos, porque Dios pone en manos de los monarcas las riendas del gobierno" 26 .

c) Por último, a noção de paradigma admite um grau nada desprezível de discrepância interna, possivel justamente pela comunhão dos pressupostos ontológicos e metodológicos principais, algo que, além de facilitar a controvérsia doutrinal (muito em voga na época), permite 0 desenvolvimento de políticas e a construção de aparatos judiciais diversos: 
Indiano (=Anuario Histórico-Jurídico Ecuatoriano, V). Quito: Ediciones Corporación de Estudios y Publicaciones, 1980, I, p.311-359; PIETSCHMANN, Horst. Burocracia y corrupción en Hispanoamérica colonial. Una aproximación tentativa. Nova Americana, n.5, p.11-37, 1982

37

Tal como Felipe $V$ adverte a seus magistrados nas Indias pela RC 31.I.1726, qualquer vassalo agravado tenha "el arbitrio de recurrir a mi directamente, por medio del... mi secretario de estado y del despacho, a fin de que enterado yo de su instancia (si fuera cierta) pueda tomar las mas justas providencias" (MATRAYA Y RICCI, Juan Joseph. Op. Cit., n.515; RUIZ GUIÑAZÚ, Enrique. Op. Cit., p.357-358, por donde cito). Para além disso, basta para o meu propósito remeter genericamente às disposições relativas às Audiencias que citam ou recolhem: LEBRÓN, em seus comentários já citados (nota 32); AYALA, Manuel José de Diccionario de Gobierno y Legislación de Indias. Ed. de Marta Milagros del Vas Mingo. 13 vols. Madrid Ediciones de Cultura Hispánica, 1988-1996; Idem, Notas a la Recopilación de Indias. Origen e historia ilustrada de las leyes de Indias. Transcripción y estudio preliminar de Juan Manzano. Madrid: Ediciones Cultura Hipánica, 1945; GARCIAA GALLO, Concepción. Las notas a la Recopilación de Leyes de Indias, de Salas, Martínez de Rozas y Boix. Madrid: Ediciones Cultura Hispánica del Centro lberoamericano de Cooperación, 1979. Assim como, MATRAYA Y RICCl, Juan Joseph. Op. Cit.; y VENTURA BELEÑA, Eusebio. Recopilacion sumaria de todos los autos acordados de la Real Audiencia y Sala del Crimen de esta Nueva España, y providencias de su Superior Gobierno; de varias Reales Cédulas y Ordenes que despues de publicada la Recopilacion de Indias han podido recogerse asi de las dirigidas á la misma Audiencia ó Gobierno, como de algunas otras que por sus notables decisiones convendrá no ignorar. Impresa en México por Don Felipe de Zúñiga y Ontiveros, 1787; ed. facs., con "Estudio introductorio" de María del Refugio González. México: UNAM, 1991, da qual interessa agora a parte devida ao próprio Ventura, com portadas e paginação independente (I, p.1-373), e as cópias que publica en el t. Il (Copias a la letra ofrecidas en el primer tomo de la Recopilacion sumaria [...]). Vejam-se também as abundantes notícias que traz OTS CAPDEQUI, José María. Nuevos Aspectos del Siglo XVIII Español en América. Bogotá: s. n., 1946. p.42-87; e Instituciones de Gobierno del Nuevo Reino de Granada Durante el Siglo XVIII. Bogotá: Universidad Nacional de Colombia, 1950. p.63-143.

38

Como sem nenhum eufemismo reconheceu Felipe V no seu RD 10.II.1715, já cit. (nota 26), e o Consejo não deixou de advertir, com grande alarme, como guardião da conciência principesca: assim, p.e., "Consulta del Consejo de Indias sobre los inconvenientes que resultan en beneficiar los oficios en Indias, y especialmente los puestos de justicia y gobierno" (Madrid, 9.XI.1693), apud KONETZKE, Richard. Colección de Documentos para la Historia de la Formación Social de Hispanoamérica, 1493-1810. 3 Vols. Madrid: Consejo Superior de Investigaciones Científicas 1953-1962, vol.III-1:18, p.34-39; e a consulta de 1737 que resumem BURKHOLDER, Mark A.; dentro do mesmo paradigma de justiça cabem distintos modelos judiciais, ou seja, distintas articulações institucionais para a realização da justiça que não é por partilharem os mesmos pressupostos últimos que resultam serem irrestritamente intercambiáveis.

Não é este o caso das Índias, cujo aparato judicial foi constituído ao modo castelhano, conforme os critérios estabelecidos pelos Reis Católicos e revalidados pelos Áustrias para a administração da justiça nos termos apontados. ${ }^{27}$ Quais foram, então, os critérios que presidiram o governo da justiça nas Índias?

Foram aqueles adequados a um mundo que, passada a Revolução e por contraste, chamamos de incerteza jurídica. A ideia central sobre a qual se assenta todo o aparato judicial é a da confiança dos pleiteantes na justiça oficial, que faz da imagem ou aparência de imparcialidade um requisito essencial para o seu funcionamento. Como a incerteza desaconselhava a motivação das sentenças e a justiça, por consequência, não aparecia objetivada no julgamento, permanecendo encerrada na consciência do julgador, a única garantia possível de justiça era uma garantia moral, por completo dependente do comportamento justo exteriorizado pelo juiz.

Isto explica as características mais sobressalentes do aparato de justiça, que são duas: a) a estrita disciplina da imparcialidade e do consenso determinantes da decisão, articulado por meio do chamativo isolamento social dos magistrados e do rigoroso segredo dos motivos da decisão, que deve servir principalmente para ocultar qualquer discrepância, criando diante de todos uma aparência de unanimidade; b) a extraordinária importância adquirida pelo consenso na definição da justiça, isto é, a espontânea confluência em uma mesma decisão do número de juizes legalmente pré fixados, que se alcança tanto mediante o acúmulo de instâncias como pela coincidência dos juízes de um mesmo tribunal nas de caráter supremo. A justiça é, afinal, uma questão de quantidade: tanta justiça tem a parte como votos recebe sua causa.

Muito fortemente resumido, este é o conteúdo essencial das Ordenanzas dos tribunais no relativo à disciplina da conduta de seus juízes, e não por casualidade a mesmo cabe reconduzir também a maior parte das causae recusationes (que têm por objeto garantir a imparcialidade, e não são mais do que uma tradução juridica do tecido das relações sociais dominantes). ${ }^{28}$ Cada qual a seu modo, umas e outras servem ao fim de construir na prática a figura do juiz perfeito: as primeiras mediante a disciplina da pessoa pública do juiz e as últimas como garantia frente à sua pessoa privada.

Em suma: se, e somente se, os juizes se comportam de modo imparcial, votam livremente (em consciência) e mantém em segredo os seus motivos, as sentenças aparecerão como imparciais ante a opinião das gentes. Nisto consiste, nem mais nem menos, a boa (ou exata) administração da justiça.

Uma justiça, portanto, de juízes, e não de "leis", já que concentrava a garantia na pessoa e não na decisão dos juízes: como, ao fim e ao 
CHANDLER, Dewitt S. Creole Appointments... Op. Cit., p.194-198.

39

Assim, após vender cargos de justiça a naturais até 1711, Felipe $V$ ordenou a seu virrey no Perú, mediante a RC 27.IV.1720, que repreendesse os magistrados das Audiencias que "proceden en los negocios en que intervienen con demasiada pasion, dexandose imprudentemente llevar de las adherencias de parentescos, que por si, o por sus mujeres tienen, empeñandose por estos motivos y otros fines particulares con demasiada vehemencia, en la proteccion de los intereses de sus parientes y dependientes" (MATRAYA Y RICCI Juan Joseph. Op. Cit., n.458; RUIZ GUIÑAZÚ, Enrique. Op. Cit., p.121-122, por donde cito). Para o argumento delineado no texto, remeto ao meu El corregidor en Cataluña, pp. 576-577.

40

A expressão é de LYNCH, John. El reformismo borbónico... Op. Cit., p.44-45.

41

Além dos trabalhos de BURKHOLDER, Mark A. e CHANDLER, Dewitt S. citados na nota 36, podem ser vistos para isto, entre outros: CAMPBELL, Leon G. A Colonial Establishment: Creole Domination of the Audiencia of Lima During the Late Eighteenth Century. Hispanic American Historical Review, v.52, n.1, p.1-25, 1972; BURKHOLDER, Mark A. From Creole to Peninsular: The Transformation of the Audiencia of Lima. Hispanic American Historical Review, v.52, n.3, p.395-414, 1972; LOHMANN VILLENA, Guillermo. Los ministros de la Audiencia de Lima en el reinado de los Borbones (1700-1821). Esquema de estudio sobre un núcleo dirigente. Sevilla: EEHS, 1974. p.xIvii-Ixxii; HERZOG, Tamar. La administración como fenómeno social: la justicia penal de la ciudad de Quito (1650-1750). Madrid: Centro de Estudios Constitucionales, 1995. p.54-58. Mesmo relativos à administração financeira, interessa consultar também, por sua abordagem geral: ANDRIEN, Kenneth J. The Sale of Fiscal Offices and the Decline of Royal Authority in the Viceroyalty of Peru, 1633-1700. Hispanic American Historical Review, v.62, n.1, p.49-71, 1982; Idem. Corruption, Inefficiency and Imperial Decline in the Seventeenth-Century Viceroyalty of Peru. The Americas, n.41, p.1-19, 1984.

42

Representação de Areche ao rei: Lima, 20.II.1778 (apud FERNÁNDEZ ALONSO, Serena. Presencia de Jaén en América: la Visita General de Jorge de Escobedo y Alarcón al Virreinato del Perú en el siglo XVIII (1782-1788). Diputación Provincial de Jaén, 1991, p.253, n.43.

43

Carta do cabildo secular de Lima a SM, 27.I.1699, cit. por DE LA PUENTE BRUNKE, José. Sociedad y administración de justicia: los ministros de la Audiencia de Lima (siglo XVII). In: XI Congreso del Instituto Internacional de Historia del Derecho Indiano, III, p.335-349, esp.346. Segundo escrevia Amat, virrey do Perú, al rey (Lima, 13.I.1762), os oidores estavam "por la maior parte abandonados al capricho, y a sus propios yntereses, [...] innodados de tales relaciones, assi de parientes como de intereses, comercios, y correspondencias que aunque quisieran variar de conducta les es poco menos que imposible desentenderse de las contraiciones con que estan cabo, a justiça não é o resultado das segundas senão que depende dos primeiros, não é preciso garantir a devida aplicação das "leis" senão o reto comportamento dos juizes. Ainda em 1785, Escobedo sintetivaza toda a sua experiência como visitador da Audiencia de Lima, recomendando com muito empeho a cuidadosa seleção dos juízes, pois a observância das leis e a reta administração da justiça, argumentava, "penden siempre del carácter y virtudes de los sujetos que componen los tribunales"29. A expressão mais enfática dessas concepções se encontra, sem dúvida, na tratadística de iudice perfecto, tão característica dos séculos modernos, que ainda no Setecentos conservava todo o seu vigor, embora seja verdade que principalmente acomodada nas estâncias mais baixas - mas talvez mais eficazes também - do edifício doutrinal, os dedicados à prática. Ali encontramos, para mencionar um bom exemplo, a exitosa Librería de jueces de Manuel Silvestre Martinez (uma daquelas obras dirigidas a pessoas sem biblioteca, concebidas e escritas para ensinar tudo o que se considera necessário para o desempenho da judicatura), cuja biografia lhe credita um bom conhecimento sobre a realidade judicial indiana. Ali encerra em trinta regras, derivadas principalmente do temor de Deus, "quanto conduce á la integridad de un Alcalde perfecto"30. Este era ainda, como sempre foi, o ideal de juiz, o mesmo que as disposições régias pretendiam declaradamente trasladar à realidade cotidiana, esculpindo sua figura a golpe de obrigações e proibições, isto é, conferindo ao dever ser jurídico que vigora no paradigma da justiça uma precisa roupagem regulamentária.

Não se deve tomar essa expressão - ideal de juiz - de maneira superficial, a começar pelo fato de ter inspirado durante séculos a política judicial da monarquia, cifrada na expressão "boa administração da justiça". É verdade que a sua plena realização teria feito dos magistrados algo assim como "guardiões platônicos" 31 , e isto era impossivel em uma sociedade articulada mediante vínculos familiares e outras solidariedades coletivas, mas também é certo que precisamente por isso então resultava necessário. Daí a tensão que atravessa permanentemente o universo da justiça: as inclinações da pessoa privada frente às obrigações da pessoa pública que concorrem em todo juiz, como sublimação da luta que sustenta a virtude e as paixões no interior de cada um. ${ }^{32}$ Não por acaso a consciência, que é o cenário deste enfrentamento, ficava desde um princípio pretensamente blindada por meio do juramento prestado como requisito para tomar posse do ofício, com o resultado de fazer de seu exercício uma interminável sucessão de dilemas morais ${ }^{33}$. Esta tensão pessoal (que obviamente é a determinante), movida ao plano institucional convertia os magistrados, ao mesmo tempo, em meios ou instrumentos e obstáculos à política régia ${ }^{34}$, com a consequência de redobrar a importância da recusa, elevar a primeiro plano a responsabilidade e obrigar a manutenção de uma política judicial constantemente vigilante ${ }^{35}$. 
afectos assi en esta Ciudad, como en las mas de la Jurisdiccion de esta Audiencia [...]". El virrey Amat da cuenta al rey de los defectos y vicios de organización del virreinato del Perú.- 1762. Revista de la Biblioteca Nacional, Buenos Aires, n.VII, 1942, p.345-350, esp. p.347-348

44

Nas palavras de Santo Tomás, a quem se deve sua formulação mais nítida: "...homines qui habent de aliis iudicare, saepe, propter iustitiam, multos adversarios habent. Unde non est passim credendum testibus contra eos, nisi magna multitudo conveniat" (Summa Theologiae, 2-2, q. 70, a. 2: III, p. 449). Recolhido entre nós nas Partidas 7.1.11, foi, sem dúvida, um dos argumentos mais difundidos e frutíferos em matéria de responsabilidade judicial: vejase, p.e.: SOLÓRZANO Y PEREYRA, Juan. Op. Cit.,lib.V, cap.X, n.18 (II, p.165); LARREA, Juan Bautista. Nouarum decisionum Sacri Regii Senatus Granatensis Regni Castellae pars prima [-secunda]. Lugduni, sumptibus Philippi Borde, Laurentii Arnaud \& Claudii Rigaud, 1658, dec. XCVIII, núms. 23-27, II, p.223-224).

45

Os principais foram reunidos e resumidos por EZQUERRA, Ramón. La crítica española de la situación de América en el siglo XVIII. Revista de Indias, n.87-88, p.160-287, 1962.

46

Para o primeiro, basta aqui remeter a VILLARROEL, Hipólito. Enfermedades políticas que padece la capital de esta Nueva España, en casi todos los cuerpos de que se compone y remedios que se le deben aplicar para su curación si se requiere que sea útil al rey y al público. Estudio introductorio de Beatriz Ruiz Gaytán. México: Consejo Nacional para la Cultura y las Artes, 1994. p.91-92 (e, em geral, toda sua segunda parte, p.77-136), escrito em plena fase reformista (c.1785). Bom exemplo desse último são: SEIJAS Y LOBERA, Franscisco de. Gobierno militar y político del reino imperial de la Nueva España (1702). Estudo, transcrição e notas de Pablo Emilio PérezMallaína Bueno. México: UNAM - IIH, 1986; e o sempre respaldado informe de JUAN, Jorge y ULLOA, Antonio. Noticias Secretas de América [...]. Ed. facs. de la llevada a cabo por David Barry en Londres, Imprenta de R. Taylor, 1826. Madrid: Ediciones Istmo, 1992.

47

Não obstante, no Informe general que en virtud de real órden instruyó y entregó el Excmo. Sr. Marqués de Sonora siendo visitador general de este Reyno al Excmo. Sr. Virrey Frey D. Antonio Bucarely y Ursua con fecha 31 de diciembre de 1771. [...]. Publicado por la Seccion de Fomento del Ministerio de Gobernacion. México: Imprenta de Santiago White, 1867, Gálvez afirmava: "Una de las circunstancias que me puso en mayor cuidado para observar de cerca la conducta de los Ministros, fué la de ver que los más son Naturales del Pays no obstante la expresa prohibición de las Leyes, pero en honor de los mismos sugetos, y en obséquio de la verdad, debo asegurar á V.E. que no he visto verificarse los incombenientes que me temía por los Parentescos y alianzas que tienen con las Familias principales de ésta ciudad y otras del Reyno, pues en semejantes casos se separan voluntariamente de conocer y votar en los
(III)

Os princípios norteadores do governo da justiça se mantiveram praticamente inalterados, mas a política judicial da monarquia experimentou não poucas alterações, atravessando, consequentemente, diferentes conjunturas. Está claro que foi particularmente adverso o período entre os meados dos séculos XVII e XVIII, quando se generalizou, à guisa de beneficio, a venda de títulos para os ofícios públicos, com jurisdição nas Índias até os niveis mais altos, comumente acompanhada de licenças para aquebrantar o rigoroso "isolamento" prescrito pelas disposições régias. Trata-se de coisa bem sabida. ${ }^{36} 0$ importante a destacar aqui é que em momento algum isto supôs um cancelamento do modelo judicial ou uma expressa abdicação de seus princípios. Ao mesmo tempo em que as exigências da Hacienda determinam a venda de ofícios, pela via da justiça continua fluindo para as Índias - canalizado pelo Consejo, é de supor que frequentemente em resposta à petições encaminhadas ao rei como instância suprema - o caudal de disposições que reafirmam os seus elementos capitais, impedindo assim, seguramente, que caiam em desuso. ${ }^{37}$ Que a política de venalidade dos ofícios era contraditória em relação a este modelo, todos o sabiam bem ${ }^{38}$, de modo que era simplesmente uma questão de prioridades, da qual somente nos importa destacar o seu sentido último: uma vez que uma e outra decisões são imputáveis ao rei, que é quem diante de Deus tem a responsabilidade de manter a justiça e a paz em seus reinos, é claro que juntas revelam - não uma mudança de orientação política, mas - uma fragmentação da vontade rea ${ }^{\beta 9}$. Por elementar (ou exótica) que possa parecer, esta constatação é, na minha opinião, imprescindivel para a compreensão da dinâmica institucional do Setecentos (e também explica a manutenção intacta do modelo de justiça indiano).

Os efeitos dessa contradição foram sentidas prontamente, e além disso foram multiplicados pelo notável desenvolvimento que as elites locais experimentaram no contexto que tem sido reputado como o da construção do Estado crioulo ${ }^{40}$. Certamente, como resultado deste processo a sociedade criolla ingressou nas Audiencias, bem diretamente, na qualidade de magistrados, ou bem indiretamente, através do matrimônio, de relações econômicas ou simplesmente por meio de laços clientelares que a permanência prolongada inevitavelmente acarretava. ${ }^{41}$ Os dados disponíveis são concludentes e demonstram que tão notável distorção na política judicial da monarquia propiciou a instalação dos interesses locais nos tribunais, não sendo de se estranhar que muitas vezes eles tenham prevalecido sobre a justiça. Em 1778, Areche escreveu resumindo sua experiência como visitador da Audiencia de Lima:

[...] aquellos Tribunales y Ministros, que situados en las regiones más remotas y apartadas ven con igual distancia el premio y el castigo: se van insensiblemente olvidando de aquellos modelos de pureza é integridad [...] subrrogando en lugar de estas justas ideas las que les va sujiriendo el Universal, continuo, y pernicioso mal exemplo, hijo de la opulencia, y de las costumbres de los Países en que viven, suelen venir a desamparar sus más sagradas obligaciones para prestarse á unas máximas 
negocios que interesan á sus Deudos, bien que, ofreciendose con frecuencia este reparo, sería lo contrario más útil al Público, y mas decoroso al Tribunal y á los Magistrados que le componen" (p. 10). Um magnífico exemplo do contraste entre magistrados arraigados e alheios ao distrito pode ser visto em: LAVALLÉ, Bernard. Le Marquis et le Marchand. Les luttes de pouvoir au Cuzco (17001730). Paris: Éditions du Centre National de la Recherche Scientifique, 1987.

48

CAMPILLO Y COSSíO, José del. Nuevo sistema de gobierno económico para la América: Con los males y daños que le causa el que hoy tiene, de los que participa copiosamente España; y remedios universales para que la primera tenga considerables ventajas, y la segunda mayores intereses. Madrid: Imprenta de Benito Cano, 1789, cap. I, § 8, p.4. Nos mesmos termos, pelas razões sabidas, se expressa: WARD, Bernardo. Proyecto económico. Ed. e estudo preliminar de Juan Luis Castellano Castellano. Madrid: Instituto de Estudios Fiscales, 1982. p.271. Cf. LORENTE, Marta. América en Cádiz. In: CRUZ, Pedro. et al. Los Orígenes del Constitucionalismo Liberal en España e lberoamérica: Un Estudio Comparado. Sevilla: Junta de Anadalucía - Consejería de Cultura y Medio Ambiente, 1993. p.19-66, esp. p.24-29.

49

Tal é, p.e., o parecer de Gálvez, que por 1760 escrevia: "en todas las Audiencia de América se han provisto anteriormente muchas plazas en naturales de la misma provincia o metrópoli donde está el Tribunal; y aunque creo que sería injusto privar a los indianos o criollos de que obtuviesen semejantes empleos, [...] convendría mucho colocarlos en Audiencia bien distantes de su origen, porque en Indias reina tanto el espíritu de partido y parcialidad que aun los compadrazgos producen una alianza estrecha, y asi están prohibidos a los ministros de Justicia, contra quienes dan legítima causa para recusarlos" ("Discurso y Reflexiones de un Vasallo sobre la decadencia de Nuestras Indias Españolas", apud NAVARRO GARCÍA, Luis. La política americana... Op. Cit., p.125-163, esp. 157; e de modo mais matizado, em seu informe como visitador (1771), já citado. Vejá-se, ademáis: EZQUERRA, Ramón. Op. Cit., p.171, p.225, p.285. Para a doutrina tradicional, SOLÓRZANO Y PEREYRA, Juan. Op. Cit.,lib.V, cap.IV, n.29-32, p.70-71.

50

Para o contexto, ainda que não inclua a América, cf. FERNÁNDEZ SEBASTIÁN, Javier. España, monarquía y nación. Cuatro concepciones de la comunidad política española entre el Antiguo Régimen y la Revolución liberal. Studia Historica.-Historia contemporánea, n.XII, p.45-74, 1994, esp. p.53-58.

51

0 conteúdo destas propostas, apresentadas na sessão de 5 de março de 1768, foi dado a conhecer por Richard KONETZKE. La condición legal de los criollos y las causas de la independencia. Estudios Americanos. Revista de la Escuela de Estudios Hispano-Americanos, v.ll, n.5, p.31-54, 1950, esp. p.45-47, reproduzindo a "parte fundamental" da argumentação, que contém, segundo afirma, "el núcleo del programa de reformas para las Indias, concebido en el reinado de Carlos III" (p. 46). 0 seguem neste ponto, p.e.: EYZAGUIRRE, Jaime. propias sólo del interés particular de un Hombre privado, pero agenas y extrañas de las Virtudes Políticas y Morales que deben adornar a un Ministro público [...]. ${ }^{42}$

Como estas palavras nos recordam, a administração da justiça então se movia em um equilíbrio muito frágil. Já observei que, a rigor, tal como o percebem os pleiteantes, a justiça resulta do comportamento imparcial, que por sua vez exige a alienação social do magistrado; e, por isso mesmo, a violação das regras que a impõem causa uma aparência de injustiça bem difícil de dissipar. 0 cabildo secular de Lima, que em fins do século XVIII se destacou, como logo veremos, por reivindicar uma mudança na política judicial em favor dos criollos, denunciava em 1699: os magistrados "se hallan muy emparentados con todas las más familias de este Reino, de calidad que pasan de más de seiscientas personas los parientes en grados conocidos de afinidad y consanguinidad, fuera de otros más remotos a quienes favorecen conforme los afectos y dependencias"43. Os mesmos juristas, que sempre foram mui diligentes na hora de realçar a sua posição, haviam construído uma doutrina para se blindarem frente a possíveis ataques dos litigantes agravados, que alguma vez chamei de tópico do "ódio ao juiz" e que implica uma presunção de retidão em favor dos magistrados ante quaisquer denúncias, nisi magna multitudo conveniat ${ }^{44}$. Esta última - o vniversal clamor del Pueblo, ao que se referia o virrey Amat em 1762 - era a situação que se vivia então. Seria muito fácil amontoar textos que denunciam, às vezes de forma brutal, a situação que atravessou o aparato judicial no século que corre entre 1650 e $1750 .{ }^{45}$ Há muitos, mas não sei se nos adiantariam grande coisa: é muito difícil quantificar a satisfação ou medir o descontentamento de sociedades complexas. Tais clamores existiram antes e continuaram existindo depois, ainda que, ao menos aparentemente, não tantos e nem tão descarnados. ${ }^{46}$ Para explicar a virada na política judicial da monarquia basta recordar que, nas condições apontadas, a boa administração da justiça era simplesmente inatingivel. ${ }^{47}$

Até onde sei, ninguém concebeu mudanças significativas na configuração da administração da justiça. As opiniões expressas por quem podia se fazer ouvir nas instâncias decisórias não denotam nenhuma concepção inovadora sobre a temática. 0 gênero dos escritos, o proyectismo, tampouco ia muito além: em qualquer caso, resulta significativo que, fossem eles quem fossem, todos entendiam que a solução para os problemas denunciados pertencia ao âmbito do cumprimento - e não ao da criação - do direito. Um texto tão característico do pensamento reformista como o Nuevo sistema de gobierno económico de Campillo não deixa espaço para dúvidas: para o reparo do Governo Político "no se necesita mas que reducir las cosas á su primitivo instituto en los mas de los puntos, quitando los abusos, que ha introducido el tiempo; y proporcionando nuestro sistema al estado presente de las cosas, segun el tiempo en que vivimos" ${ }^{48}$. As leis são perfeitas, logo basta que sejam observadas. 0 problema se circunscreve, portanto, aos meios para corrigir os abusos que dificultam a reta administração da justiça, definida em termos tradicionais. Sendo assim, não havia muitas 
Ideario y ruta de la emancipación chilena. Santiago de Chile, Editorial Universitaria, 1957. p.53-55; SANCHO, Laura. El programa de reformas del Consejo extraordinario de 1768 y la Representación mexicana de 1771. In: XXXVI Congreso Internacional de Americanistas. Actas y Memorias IV. Sevilla: La Editorial Católica, 1966. p.535-561, esp. p.539-540; BRADING, David A. Mineros y comerciantes... Op. Cit. p.61. Posteriormente, o documento foi integralmente publicado por Luis NAVARRO GARCÍA, em: El Consejo de Castilla y su crítica de la política indiana en 1768. Homenaje al profesor Alfonso García Gallo, III-2. Madrid: Universidad Complutense de Madrid, 1996, p.187-207, se bem que subestimando sua importância e equivocando o seu enquadramento, ao considerá-lo próprio do Consejo, e não do chamado Extraordinario. Sobre este e sua atuação, veja-se: CASTRO, Concepción. de. Campomanes. Estado y reformismo ilustrado. Madrid: Alianza, 1996, sub indice analítico; $e_{1}$ sobretudo: VALLEJO GARCÍA HEVIA, Jose María. La Monarquía y un ministro, Campomanes. Madrid: Centro de Estudios Políticos y Constitucionales, 1997. p.203-266

52

E acrescentou, em frase justamente célebre: "esto es lo que estrecharia la amistad y unión, y formaria un solo cuerpo de Nación, siendo los criollos que aqui hubiese otro tanto número de rehenes para retener aquellos paises bajo el suave dominio de SM" (p.205). Em termos análogos aos assinalados, se expressou o mesmo Floridablanca como redator da "Instrucción reservada que la Junta de Estado, creada formalmente por mi Decreto de este día, 8 de julio de 1787, deberá observar en todos los puntos y ramos encargados a su conocimiento y examen", nº xciv (apud ESCUDERO, José Antonio. Op. Cit., Vol.Il, p.13-157, especialmente p.48). Para outros testemunhos interessantes remeto, para abreviar as citações, a: EZQUERRA, Ramón. 0p. Cit., p.179, p.204, p.224-225, p.238.

53

Cit. por Eduardo MARTIRÉ, em: La visita de García de León y Pizarro a la Audiencia de Quito (Aporte documental). Anuario HistóricoJurídico Ecuatoriano, V, p.323-344, 1980, onde publica a RC Madrid, 7.XII.1782, p.327-330, com resolução acerca das providencias ditadas pelo visitador "para el mejor metodo y orden en el seguimiento de pleitos" (p.331-344), que é extraordinariamente interessante para o objeto destas páginas, porque declara aprovadas tão somente as que são conforme às "leyes", entre as quais se encontram precisamente as regras que afetam aos elementos fundamentais do modelo judicial: a disciplina da colegialidade e o segredo (p.337-339 y p.341-343). Cf., em igual sentido, a Instrucción que recebeu Gálvez para a visita dos tribunais de justiça da Nova España (Madrid, 14.III.1765), publicada em tradução inglesa por PRIESTLEY, Herbert Ingram. Op. Cit., p.413416; assim como VARELA MARCOS, Jesús. Los prolegómenos de la visita de José de Gálvez a la Nueva España (1766): Don Francisco de Armona y la instrucción secreta del marqués de Esquilache. $R I$, v.XLVI, n.178, p.453-470, 1986, esp.464.

54

Apud ESCOBEDO MANSILLA, Ronald. Op. Cit., p.323. 55

Para uma visão general correta, ver: LÓPEZ BOHÓRQUEZ, Alí Enrique. Las reformas de Carlos dúvidas: aqueles que escrevem sobre este particular localizam o problema no enraizamento dos magistrados, fossem peninsulares ou criollos, e por isso amiúde se insiste - de acordo com a doutrina tradicional - em que estes não podem servir na cidade ou província de sua naturalidade ${ }^{49}$; isto inclusive naquelas propostas que - agora sim, de forma relativamente inovadora - defendem a instrumentalização da política de nomeações a serviço das tarefas de construção nacional, que alguns já vislumbravam como imperiosas. ${ }^{50}$

A mais conhecida se deu no chamado Consejo extraordinario, formado - como Sala especial do de Castela - na sequência da crise de 1766, por ocasião da deliberação, dois anos depois, sobre as providências convenientes para sossegar o descontentamento gerado pela expulsão dos jesuítas do México. ${ }^{51}$ Os fiscais do Consejo, Campomanes e Moñino, acreditavam que para prevenir o espírito da independência e aristocracia que percebiam era preciso adotar medidas que fomentassem o amor $\dot{a}$ matriz que é a Espanha, formando, deste modo, um corpo unido de Nação. Em seu entendimento, uma das mais urgentes exigia igualdade ou reciprocidade na política de nomeações, isto é: "guardar la política de enviar siempre españoles a Indias con los principales cargos, Obispados y Prebendas, y colocar en los equivalentes puestos de España a los criollos"152. Mais adiante voltarei a este ponto.

Agora é possível concluir que, inquestionado o modelo de justiça decantado pela tradição, tratava-se de pôr em prática as "leis" que o articulavam, adotando-se as medidas indispensáveis para restaurá-lo em toda a sua pureza e evitar que pudesse ser novamente desvirtuado no futuro. Reforma como restauração. Precisamente por isso, no momento de maior pujança reformista o meio empregado foi a visita, que era o tradicionalmente empregado quando se tratava de corrigir e restaurar, como claramente assinalava, por exemplo, a comissão de García de León y Pizarro, em 1777: "siendo el principal objeto de la visita de esta Real Audiencia y tribunales de justicia restablecer a su antiguo ser las leyes y ordenanzas que por negligencia o malicia de los sugetos contra quienes se dirigen se hallan en el todo o en parte abolidas por su inobservancia" ${ }^{53}$. Como resumiu Escobedo após concluir a sua visita no Perú, em 1785, a reta administração da justiça depende de "la buena o mala conducta de los ministros, que no necesitan más providencias o encargos que los de nuestras santas y venerables leyes para llenar de justificación y pureza su ministerio"54.

Ao longo de todo o século, não houve nenhuma modificação legal relevante e as alterações institucionais ordenadas por Carlos III, além de escassas, responderam à lógica do modelo vigente: em 1776, foram aumentadas as praças das Audiencias e elevados os salários dos seus ministros, mas ambos tornaram a ser reduzidos em 1778, coincidindo com a criação de três novas Audiencias, todas decorrentes de necessidades específicas de seus respectivos territórios, o que não vem ao caso explorar. ${ }^{55}$

Uma das reformas mais significativas - esta, sim, irreversível - foi 
III en las Audiencias americanas. Boletín de la Academia Nacional de la Historia, v.LXVI, n.262, Caracas, 1983 p.319-342; reunido também no seu Los ministros de la Audiencia de Caracas (17861810). Caracterización de una élite burocrática del poder español en Venezuela. Caracas: Academia Nacional de la Historia, 1984, p.27-57. Veja-se também: SOBERANES FERNÁNDEZ, José Luis. La administración superior de justicia en Nueva España. Boletín Mexicano de Derecho Comparado, n. S., año XIII, n.37, 1980, p.143-200; FERNÁNDEZ ALONSO, Serena. Op. Cit., p.245-268, que aporta dados interessantes sobre as praças; assim como os trabalhos citados nas notas seguintes.

\section{6}

Para este último, veja-se, p.e., a ata da sessão da Junta Suprema de Estado celebrada em 13.IV.1789, na qual se adota certa decisão "para uniformar las prácticas de aquellos dominios con las de España, a fin de escusar en todo lo posible diferencias en el govierno de la monarquía", apud ESCUDERO, José Antonio. Op. Cit., p.381.

\section{7}

FERNÁNDEZ ALBALADEJO, Pablo. La monarquía de los Borbones, recolhido nos seus Fragmentos de monarquía. Trabajos de historia política. Madrid: Alianza, 1992, p.353-454, esp. p.361.

\section{8}

Para tudo isso, me seja permitido remeter aos meus: Las Ordenanzas de la Real Audiencia de Cataluña (1742). (Una contribución al estudio del régimen de la Nueva Planta). Initium, n.1, 1996, (=Homenatge al Prof. J. M. Gay i Escoda), p.371396; Despotismo llustrado y desorden social: la restauración de la nueva planta de la Audiencia de Cataluña (1775). Initium, n.2, p.485-516, 1997, onde está citada a bibliografía pertinente.

\section{9}

RC Aranjuez, 20.VI.1776: "Instrucción de lo que deben observar los regentes de las Reales Audiencias de América: sus funciones, regalias, cómo se han de haber con los virreyes y presidentes, y éstos con aquéllos" (facilmente acessivel em SÁNCHEZ-ARCILLA BERNAL, José. Op. Cit., p.389-399, por onde se cita), na qual são detalhados os casos nos que podem atuar por si e aqueles em que têm de fazê-lo em coordenação com o presidente. Cf. SOBERANES FERNÁNDEZ, José Luis. El estatuto del regente de la Audiencia de México (1776-1821). Anuario de Estudios Americanos, n.XXXII 1975, p.415-446; e MARTIRÉ, Eduardo. Los regentes de Buenos Aires. La reforma judicial indiana de 1776. Universidad de Buenos Aires, 1981, que remetem à bibliografia anterior.

60

Instrucción, cap. 43. Um de seus principales cuidados será "el informarse con frecuencia del estado que tienen los Pleytos en las Audiencias, para evitar el que se impida su curso y determinación por medios ilegítimos, y dará las ordenes correspondientes a fin de que la Justicia tenga el debido y pronto servicio que corresponde" (cap. 29).

61

Instrucción, caps. 16-19, 22-27, 37, 39, 41 y 56. Não será necessário recordar a cuidadosa economia organizativa implantada pelas Ordenanzas para garantir a mútua independência de critério dos juizes no seio dos tribunais, por a introdução da figura do regente. Como não se estudou a gênese da real cédula de 20 de junho de 1776 que o instituiu em todas as Audiencias, desconhecem-se as razões determinantes desta decisão, mas parece claro - à falta de explicação melhor - que era uma medida coerente com a política da Coroa após os graves acontecimentos de 1766 e adequada, por isso, à diretriz de uniformizar a administração de seus domínios que a animava. ${ }^{56}$ Explico-me. Como sabido, a figura do regente em si mesma não envolvia nenhuma novidade no panorama institucional castelhano, porém, no início do século XVIII, ao calor do estilo de governo praticado por Felipe $V$, ela assumiu uma nova dimensão: logo, a imposição da nueva planta nos reinos da Coroa de Aragão manifestou "la configuración militar del entramado político-administrativo del reino" que impulsionava a nova dinastia. ${ }^{57}$ Após intenso debate, decidiu-se instituir, como órgão supremo de justiça e governo de cada reino, uma Audiencia dirigida por seu regente e presidida pelo correspondente Capitán general. Como alguém já disse, ficava assim constituído um cuerpo místico, o Real Acuerdo, formado pela união de todos os oidores com o regente, sob a presidência do Capitán general (quem "há de ter voto somente nas coisas de governo"), para tratar e decidir os assuntos do reino. Muito provavelmente, a razão determinante desta decisão foi atenuar os conflitos entre ambos os gêneros de autoridades - militar e togada -, que de outro modo se sabiam inevitáveis. Porém, na Catalunha, não chegou a funcionar da forma ordenada, pois o Capitán general atuou ali, de facto, mas com expresso consentimento real, como se fosse um virrey, apesar dos múltiplos conflitos e das reiterados queixas da Audiencia. Militarismo vs. civilismo, tem-se dito, é uma das chaves explicativas da dinâmica institucional do Setecentos. Segundo os partidários do segundo, no terço final do século, era necessário - nas palavras de Campomanes - "restablecer los principios fundamentales de la monarquía, que en tiempos anteriores fueron enerbados", entendia-se que com graves consequências para a paz e a justiça em seus domínios. Em 1774, com esse preciso argumento, foi restaurada em toda a sua integridade a nova planta da Audiencia da Catalunha, em detrimento das faculdades que vinha exercendo o seu presidente militar. ${ }^{58}$

Embora se referisse somente à administração da justiça (e apenas indiretamente ao governo), a introdução dos regentes nas Audiencias das Índias, ocorrida dois anos depois, deve ser inserida neste contexto. Mutatis mutandis esse debet. 0 presidente manteve o status de cabeça do corpo da Audiencia, mas as funções de governo interior que como tais the correspondiam passaram a ser próprias do regente, que também assumiu as de direção exercidas pelo oidor decano ${ }^{59}$. Era este um fim em si mesmo? Parece claro que não, que a redução do peso do elemento militar nos tribunais busca facilitar a boa administração da justiça, que por outro lado é o objeto pública e reservadamente declarado da reforma. Afinal, aquelas Províncias, "por lo distantes de esta Península, necesitan de mayor esmero y rectitud en la imparcial administración de justicia"60. Por isso, a Instruc- 
razão de sua importância; tal como García de León y Pizarro ordenou aos oidores de Quito por auto de 7.IX.1779: "Que al tiempo de votar los pleitos se observe el mismo silencio y gravedad, [...] sin atravesarse cuando otro está sentando su razón, votando cada cual libremente, [...] alejando de la votación toda alternación y argumentación y antes bien manejándose con frescura sin pasión ni queriendo sigan los demás el propio dictamen, porque esto debe dejarse a que lo obre la fuerza de la razón y del fundamento de hecho o de derecho que se propusiese" (apud MARTIRÉ, Eduardo. La visita de Garcia... Op. Cit., p.343).

62

MARTIRÉ, Eduardo. Los regentes... Op. Cit.,mas, especialmente, para o que aqui importa, p.33-42, p.47-50, p.60-86, p.104-137, p.143-147, p.155156 , etc. (as citações, nas p.75 y p.307). Veja-se também MARILUZ URQUIJO, José María. Las memorias de los regentes de la Real Audiencia de Buenos Aires Manuel Antonio Arredondo y Benito de la Mata Linares. Revista del Instituto de Historia del Derecho, 1, 1949, p.19-26.

63

Remeto, por abreviar as citações, a SUÁREZ, Santiago Gerardo. Las Reales Audiencias indianas. Fuentes y Bibliografía. Caracas: Academia Nacional de la Historia, 1989. p.411-497, que deve se completar com os trabalhos que cito nas notas seguintes.

64

Cf. SÁNCHEZ-ARCILLA BERNAL, José. Op. Cit. p.52-54, p.58-61 y, para os textos respectivos das Audiencias de Cuzco e Caracas, p.401-489. As Ordenanzas da Audiencia de Buenos Aires foram já publicadas por RUIZ GUIÑAZÚ, Enrique. 0p. Cit., p.371-431

65

Carta do regente Portilla ao virrey (26.III.1788), apud RUIZ GUIÑAZÚ, Enrique. Op. Cit., p.136. Assim o confirma a simples leitura dos textos e aqueles que se ocuparam de cotejá-los assim o detalham.

66

Vejam-se, respectivamente, RRCC Madrid, 14.IV.1783 y 22.I.1790, assim como as mesmas Ordenanzas (Buenos Aires, 23.IV.1786), que reproduzem as de 1661, apenas com a omissão de três capítulos: apud RUIZ GUIÑAZÚ, Enrique. Op. Cit., p.368-432.

67

Cf. MORAZZANI DE PÉREZ ENCISO, Gisela. Materiales para el estudio de una ordenanza del siglo XIX. Revista de la Facultad de Derecho de México, v.XXVI, n.101-102 (=IV Congreso Internacional de Historia del Derecho Indiano) 1976 p.447-464; o que se deve complementar com as indicações de Ali Enrique LÓPEZ BOHÓROUEZ. La Real Audiencia de Caracas (Estudios). MéridaVenezuela: Ediciones del Rectorado de la Universidad de los Andes, 1998. p.112-118.

68

A frase do regente Portilla citada antes (n.65) continuava assim: "si bien no dejo de advertir que segun el actual estado de las cosas y el nuevo metodo o forma que se ha dado al gobierno de estos reinos, hay bastante que alterar en aquellas (Ordenanzas), añadiendo, quitando o mudando algunos de sus articulos para que puedan adaptarse al presente sistema". ción que os institue cria um âmbito de atuação próprio para o regente, dotando-o da autoridade necessária para exercê-lo. Isto é evidente nas disposições relativas ao cerimonial; e aquilo fica concentrado, à vista da Instrucción, na estrita disciplina da colegialidade, condição imprescindivel à imparcialidade (ou seja, da justiça). ${ }^{61}$ Assim o demonstra claramente, na medida em que sabemos, o trabalho desenvolvido pelos regentes, tanto pela via negativa dos conflitos que a sua introdução suscitou, quanto pela positiva da atuação que efetivamente desempenharam. Os abundantes testemunhos sobre o particular apresentados por Martiré não deixam dúvidas: os regentes foram instruídos para garantir o cumprimento de las reglas de derecho y justicia que observan los tribunales superiores, a quem principalmente está encargada la administración de justicia. ${ }^{62}$

A única que ainda em fins do século era institucionalmente viável. 0 marco jurídico - o modelo - não experimentou nenhuma alteração. $\mathrm{Na}$ última parte da centúria foram criadas, por esta ordem, as Audiencias de Buenos Aires, Cuzco e Caracas, cada uma em atenção a circunstância peculiares de seus territórios e todas, ao final, com o resultado de tornar ali visivel a presença fictícia do rei - se assim se pode dizer, como creio -, que o selo real evidenciava, isto é, constituindo outras tantas instâncias ordinariamente supremas ${ }^{63}$. Todas, em cumprimento de suas respectivas disposições constitutivas, começaram a funcionar com as Ordenanzas de algum dos tribunais já existentes e todas terminaram por elaborar as suas próprias. ${ }^{64}$ São coisas sabidas. Entre as primeiras não havia diferenças substanciais: "todas las encuentro iguales - disse o regente de Cuzco -, con muy poca diferencia en lo substancial, como que todas ellas son deducidas de unas mismas leyes y todas se encaminan a un propio fin"65. Qual o sentido, então, de elaborar novas Ordenanzas? Acaso não bastava a mera transcrição das existentes? Segundo as disposições constitutivas desses tribunais, é claro que não. A de Buenos Aires, por exemplo, ordenava à Audiencia "formar sin la menor dilacion las correspondientes ordenanzas para su buen regimen y gobierno", tendo presentes as de Lima, as de Charcas e as que em 1661 haviam sido formadas ali mesmo, "arreglandose para su formacion a lo dispuesto en las Leyes, adoptandose [sic] al actual estado de las cosas". De fato, as elaboradas em cumprimento deste mandato foram desaprovadas, com a ordem de se formar outras novas "sin incluir en ellas lo que esta resuelto y ordenado por las leyes, por la Instruccion de Intendentes y de Regentes: limitandose unicamente a lo economico y peculiar del mismo Tribunal segun las circunstancias de su territorio y a las ultimas Reales Cedulas y ordenes" remetidas. ${ }^{66}$ Algo similar ocorreria na Audiencia de Caracas. ${ }^{67}$ Em ambos os casos, porém, a ordem real reprobatória não foi dirigida ao parecer óbice para que as Ordenanzas continuassem vigentes. 0 problema não residia no modelo de administrar a justiça, mas, principalmente, na incidência que tinham sobre as funções ou faculdades das $\mathrm{Au}$ diencias as modificações experimentadas pelo sistema de governo em seu conjunto (como mais adiante veremos, ao menos de passagem). ${ }^{68}$ Basta ler 
Cf., especialmente, Ordenanzas (Cuzco, 26.X.1789), caps.2 in fine, 5-6, 10, 11 in princ., 12, 14-17, 73-74.

70

Por serem as últimas e resultado, ao que parece, de um longo e meticuloso trabalho de recopilação as Ordenanzas de 1805 nos aparecem, em tudo que se refere à administração da justiça, como a culminação do que desde então pode ser chamado, com razão, "modelo judicial espanhol". Para o primeiro, veja-se a documentação que publica ALBORNOZ DE LÓPEZ, Teresa. La visita de Joaquín Mosquera y Figueroa a la Real Audiencia de Caracas (1804-1809): conflictos internos y corrupción en la administración de justicia. Caracas: Academia Nacional de la Historia, 1987. p.161-190.

71

É questão abundantemente documentada e bem conhecida, principalmente graças aos trabalhos de RIPODAS ARDANAZ, Daisy. El Matrimonio en Indias. Realidad social y regulación jurídica. Buenos Aires: Fundación para la Educación, la Ciencia y la Cultura 1977, que reuni a maior parte das referências conhecidas, p.317-349, esp.327-328, p.334-337, p.341-342 e p.346-349; e BURKHOLDER, Mark A.; CHANDLER, Dewitt S. De la impotencia... Op. Cit., p.131, p.137-138, p.155-162.

72

RC Buen Retiro, 23.I.1754, que "consideradas las dudas que suele ocasionar la varia inteligencia dada" à lei (RI 2,16,82), depois de certas decisões de Felipe $V$ que pareciam circunscrever a proibição ao matrimônio com naturais (vid. el RD 27.IV.1750 que se menciona em AYALA, Manuel José de. Diccionario... Op. Cit., s. v. "Matrimonios", n.22) ordena que "se observe en todo su vigor [sic]" (apud KONETZKE, Richard. La prohibición de casarse los oidores o sus hijos e hijas con naturales del distrito de la Audiencia. In: Homenaje a don José María de la Peña y Cámara. Madrid: José Porrua Turanzas, 1969. p.105-120, esp. p.110-111; MATRAYA Y RICCI, Juan Joseph. Op. Cit., n.681); de modo que "quedan los ministros privados de casarse sin permiso en el territorio que sirven, no sólo con mujer natural de él, sino también con la que no lo es", segundo interpreta o Consejo de Indias em consulta de 2.X.1764, em atenção às dúvidas expressadas pelo virrey do Perú (KONETZKE, Richard. Colección de Documentos... Op. Cit., Vol.III-1, 193, p.321), que deu lugar à RC 23.XI.1764, referida por MATRAYA Y RICCI, Juan Joseph. Op. Cit., n.809. Veja-se, também: AYALA, Manuel José de. Notas a la recopilación... Op. Cit., p.281; asi como las Notas de LEBRÓN y de MARTÍNEZ DE ROZAS, ya citadas (GARCIA GALLO, Concepción. José Lebrón y Cuervo... 0p. Cit., p.423-424; Idem. Las notas a la Recopilación... Op. Cit., p.100). La RO 28.II.1793 substituiu em tais casos a licencia real pela outorgada pelo virrey ou pela autoridade superior correspondente (OTS CAPDEQUÍ, José María. Instituciones de Gobierno... Op. Cit., p.128). Cfr., para todo esto, RíPODAS ARDANAZ, Daisy. Op. Cit., p.336-337)

73

BURKHOLDER, Mark A.; CHANDLER, Dewitt S. De la impotencia... Op. Cit., p.159-162, a propósito dos "montepíos de ministros y oficinas", que supuseram o fim dos matrimônios clandestinos, que antes ocorreram: um exemplo de 1770 pode as Ordenanzas (estas sim, aprovadas) da Audiencia de Cuzco. ${ }^{69}$ Em suma, formulados de um modo ou de outro - mas quase sempre do mesmo -, os critérios que deviam reger a justiça superior permaneceram incólumes: antes, durante e depois do reinado de Carlos III, ao longo de todo o século XVIII, como nos anteriores. ${ }^{70}$

Por isso, a mudança fundamental afetou os homens, não as leis: fez-se visível, como sabido, na política judicial praticada pela Coroa e, em princípio, não se refletiu em disposição normativa alguma. Tal como Burkholder e Chandler demonstraram de modo exaustivo, a partir de 1750 foi posto fim ao benefício de ofícios com jurisdição, retornando-se à provisão ordinária das auditorías, baseada nas qualidades (e não no bolso) dos pretendentes, com o resultado de reduzir drasticamente, ao cabo de poucos anos e em especial após o aumento de praças de 1776, o número de oidores criollos nos tribunais americanos. Essa foi a mudança fundamental em todos os sentidos, inclusive no quantitativo: se temos em conta que na primeira metade do século três quartos dos magistrados criollos obtiveram o cargo por dinheiro há de se concluir que o número de nomeados pelos meios ordinárias a partir de então não descendeu, senão que inclusive aumentou. De qualquer modo, encerrava-se assim um parêntesis de quase sessenta anos.

A peninsularização das Audiencias não esgotou a volta à política judicial tradicional. Como põem muito bem em manifesto os historiadores citados, desde meados do século e especialmente a partir de 1776-77, foi feita uma aplicação visivelmente mais rigorosa dos critérios decantados pela tradição para o governo da justiça, com o fim de impedir o enraizamento dos oidores forâneos em seus distritos. Por um lado, não somente foram também suspendidas as vendas de licenças para a contração de matrimônio, senão que se estreitou ainda mais o círculo da proibição ${ }^{71}$ : em 1754 foi posto fim à interpretação restritiva que vinha se reproduzindo ao amparo da tolerância (ou omissão) real, reafirmando-se com todo o rigor a lei proibitiva ${ }^{72}$; e nas décadas seguintes foram arbitrados meios de controle mais eficazes para o favorecimento do seu exato cumprimento. ${ }^{73}$ Mesmo sendo muito difícil identificar tendências gerais a partir de dados provavelmente fragmentários em se tratando de um assunto como esse, alguns testemunhos sugerem que, na segunda metade do século, as dispensas da proibição se outorgaram com grande cautela, a fim de evitar os prejuízos que de modo mais claro podiam acarretar os casamentos. ${ }^{74}$ Por outro, uma série coordenada de medidas adotadas na época de Gálvez facilitaram o movimento periódico - a rotación dos magistrados, evitando a sua radicação no distrito. ${ }^{75}$

Em conclusão, a partir de meados do século a Coroa aplicou com renovado vigor o seu programa tradicional de governo da justiça, considerado imprescindivel para o alcance da imparcialidade dos juízes. Se o que se pretendia era garantir a imparcialidade (ou o que é igual, a posição do juiz como mediador da justiça comutativa), então deviam ser erradicadas as relações que criavam nos magistrados obrigações mais poderosas que 
ser visto em AYALA, Manuel José de. Diccionario... Op. Cit.,n.32; e, em general, RÍPODAS ARDANAZ, Daisy. Op. Cit., p.340-341.

74

Segundo os dados de BURKHOLDER-CHANDLER, entre 1778 y 1808, contabilizavam 18 licenças e 22 "fueron denegadas, concedidas bajo condición de que el interesado aceptara un inmediato cambio de sede o dieron motivo a medidas punitivas". BURKHOLDER, Mark A.; CHANDLER, Dewitt S. De la impotencia... Op. Cit., p.157-159). La RO 24.III.1791 reiterou novamente a proibição (MATRAYA Y RICCl, Juan Joseph. Op. Cit., n.1668; Las notas a la Recopilación... Op. Cit., p.101).

75

BURKHOLDER, Mark A.; CHANDLER, Dewitt S. De la impotencia... Op. Cit., p.141 ss. y p.175 ss.

76

Cf. LAVALLÉ, Bernard. Situación colonial y marginalización léxica: la aparición de la palabra criollo y su contexto en el Perú (1986), recolhido no seu Las promesas ambiguas. Ensayos sobre el criollismo colonial en los Andes. Lima: Instituto Riva-Agüero (PUCP), 1993. p.15-21, destacando o matiz pejorativo com que nasce o termo. Os dados demográficos procedem de LYNCH, John. El reformismo borbónico... Op. Cit., p.38-40.

77

Com referência ao "trasfondo ideológico y sistema de representaciones que articularon el patriotismo criollo del siglo XVII" disse LAVALLÉ: "Ya en aquellos tiempos parece problemáticamente vacilante, en no pocos aspectos ambiguo, pues el protonacionalismo que subyace en él era al mismo tiempo excluyente para con los dominados de la conquista y se nutría, a pesar de su crítica a la metrópoli, en el sistema que ésta garantizaba" (LAVALLÉ, Bernard. Las promesas ambiguas... Op. Cit., p.10).

78

Mesmo faltando uma análise desde a perspectiva adequada (a meu juizo, a construção jurídica da identidade criolla, que me proponho estudar em breve) podem ser encontradas algumas referências aos escritos principais, num e noutro contexto, em: LOHMANN VILLENA, Guillermo. 0p. Cit., p.xxv-xxvi; LAVALLÉ, Bernard. Planteamientos lascasistas y reivindicación criolla en el siglo XVII: el borrador de Fr. Raimundo Hurtado (1980), ahora en LAVALLÉ, Bernard. Las promesas ambiguas... Op. Cit., p.79-101, esp. 92-95; BURKHOLDER, Mark A.; CHANDLER, Dewitt $S$. De la impotencia... Op. Cit., p.20-26, p.68; e, mui especialmente, BRADING, David. A. Orbe indiano. De la monarquía católica a la república criolla, 1492-1867. Trad. de J. J. Utrilla. México: FCE, 1991. p.250-252, p.343-344, p.413414, p.432-433, p.503-529. Veja-se também: ISRAEL, Jonathan I. Razas, clases sociales y vida política en el México colonial, 1610-1670 (1975) Trad. R. Gómez Ciriza. México: FCE, 1996. p.105, p.108-114, p.197-199.

79

"[...] y assi, aunque el que nace en Mexico, no pudiera ser Oidor alli, podia serlo en Lima, Guadalaxara, y todas las demas Audiencias de Indias". Vid. su interesantísima Representacion politico legal, que haze a nuestro soberano, Don Phelipe Quinto, (que Dios guarde) Rey poderoso de las Españas, y emperador siempre augusto de as jurídicas do cargo, evitando-se que a pessoa privada do juiz prevalecesse sobre a pública nas salas de justiça. Assim sendo, poder-se-ia dizer, sem ápice de ironia, que, especialmente a partir de então, os Bourbons (e sobretudo Carlos III) se comportaram como aquilo que eram, reis católicos, e em duplo sentido: aplicaram as regras estabelecidas a respeito por Isabel e Fernando e, ao fazê-lo, realizaram seu ofício de reis, a desencargo de sua consciência diante de Deus em uns juízes que se entendiam capacitados para a reta administração da justiça.

\section{(IV)}

Esta política judicial, na medida em que alterava o statu quo instalado durante as últimas décadas, prejudicava quando menos os interesses daqueles setores da população americana que haviam sido beneficiados pelo abandono ou relaxamento da monarquia. Por isso, não é de se estranhar que o seu cumprimento tenha sido acompanhado de protestos da elite criolla, aos quais convém dar um momento de atenção, pela importância que tiveram na interpretação mais difundida do reformismo bourbônico. $\dot{E}$ muito dificil mensurar o seu alcance, mas custa muito imaginar que houvera unanimidade neste ponto. Quando falamos de criollos, nos referimos a um coletivo de 2,7 milhões de pessoas (sobre um total de 11 milhões) repartido de modo muito desigual, preferencialmente pelas cidades de todo o continente, cujo único ponto certo em comum era o seu elemento definidor: espanhóis brancos nascidos em terras americanas. ${ }^{76}$ Não era um grupo socialmente homogêneo e é difícil crer que tivessem os mesmos interesses, mas é verdade que ao menos suas elites desenvolveram uma consciência de identidade própria (em boa medida, frente aos outros brancos, os espanhóis europeus ${ }^{77}$, que já no século XVII tinha como um dos seus componentes essenciais a reivindicação dos cargos da monarquia na América. ${ }^{78}$ De fato, os testemunhos de rechaço à política judicial conhecidos - a maior parte, por certo, proveniente da época do chamado "Estado criollo" - refletem ambas as coisas: provém de setores característicos da elite criolla, mas se apresentam como um atentado ao conjunto dos españoles indianos. A expressão é de Juan Antonio de Ahumada, advogado da Audiencia do México, que em 1725 defendeu ante Felipe $V$, de modo bastante prolixo, com argumentos de todos [os] Derechos, "que los Oficios de la America se dèn à los Españoles Indianos" e apenas a eles, ainda que admitindo como exceção o impedimento de que o Natural ò Vezino fosse magistrado em sua Ciudad ò Província, conforme prescrito no direito tradicional (recolhido nas Partidas: $1,18,11) . .^{79}$ Desse modo, em meados do século XVIII, nada disso era novidade, nem tampouco, evidentemente, o único problema que o governo da América enfrentava, mas era sim um elemento que podia catalisar o descontentamento.

0 Ayuntamiento do México, em sua conhecida Representación de 1771, defendia, com os mesmos argumentos manejados pelos tratadistas precedentes, que "los empleos [eclesiásticos y] seculares de qualquiera 
las Indias, para que se sirva declarar, no tienen los Españoles Indianos obice para obtener los empleos Politicos, y Militares de la America; y que deben ser preferidos en todos, assi Eclesiasticos, como Seculares (impresa s. I., s. d.; Biblioteca Nacional de España, mss. 19124, ff. 305-326), passim (ff. 2v y $17 v$ para las citas), que é, para todos os efeitos, um bom testemunho do paradigma da justiça.

80

Representación que hizo la ciudad de Mexico al rey D. Cárlos III en 1771 sobre que los criollos deben ser preferidos á los europeos en la distribucion de empleos y beneficios de estos reinos. México: s.d., mayo de 1771, apud Juan E. HERNÁNDEZ DÁVALOS. Colección de documentos para la historia de la guerra de independencia de México de 1808 a 1821. 6 vols. México: Imprenta de J. M. Sandoval, 1877-1882, I, 195, p.427-455, esp. p.429 y p.438, para as citações. Cf. SANCHO, Laura. Op. Cit., p.542-561; BRADING, David. A. Orbe indiano... p.517-520; NAVARRO GARCÍA, Luis. La protesta del ayuntamiento de México a favor de los criollos en 1771. In: PINARD, Gustavo E. y MERCHÁN, Antonio (eds.). Libro Homenaje In Memoriam Carlos Díaz Rementería. Universidad de Huelva, 1998. p.521-531.

81

Carta de Gálvez ao Ayuntamiento do

México (Madrid, 2.I.1778), em resposta a sua representação de 24.VII.1777, queixando-se da disposição real de 1776 (citada na nota seguinte) e de alguma outra ordem régia também mencionada. No dizer do secretário, a reserva do terço das prebendas "no excluye que haya muchos más, como siempre los ha habido, los hay y los habrá" (KONETZKE, Richard. Colección de Documentos... Op. Cit., Vol.III-1, 244, p.434-435). Por essa ocasião, também protestou o claustro universitário, nos termos resumidos por BURKHOLDER, Mark A.; CHANDLER, Dewitt S. De la impotencia... Op. Cit., p.148-149. Para reivindicações análogas do movimento comunero de Nova Granada, PHELAN, John Leddy. The People and the King. The Comunero Revolution in Colombia, 1781 (Madison, University of Wisconsin Press, 1978), p.178-181.

82

RO El Pardo, 21.II.1776 (KONETZKE, Richard. Colección de Documentos... Op. Cit., Vol.IIl-1, 234, p.405-406). Sobre esta ordem e as queixas ou representações seguidamente mencionadas, vejam-se, além dos trabalhos específicos citados nas notas seguintes: KONETZKE, Richard. La condición... Op. Cit., p.48-53; BRADING, David A. Mineros y comerciantes... Op. Cit., p.61-63; BURKHOLDER, Mark A.; CHANDLER, Dewitt S. De la impotencia... Op. Cit., p.139-140, p.147-148, p.150-151 y p.167168; LÓPEZ BOHÓRQUEZ, Ali Enrique. Las reformas de Carlos III... Op. Cit., p.338-342.

83

Para o inciso, cf. a indicação de BURKHOLDER, Mark A. From Creole to Peninsular... Op. Cit., p.400-401 y p.412; assim como BURKHOLDER, Mark A.; CHANDLER, Dewitt S. De la impotencia.. Op. Cit., p.148. Um bom testemunho do calvário seguido por um criollo para a obtenção de uma auditoria, mesmo que em sua própria pátria, BURKHOLDER, Mark A. Politics of a Colonial Career: José Baquijano and the Audiencia of Lima. Wilmington: SR Books, 1990. clase se confieran a los naturales", e apenas em atenção a que os Españoles Europeos y Americanos formam un solo Cuerpo Politico e sua pretensão significaria "querer mantener dos cuerpos separados e independientes baxo de una Cabeza, en que es preciso confesar cierta monstruosidad política", aceitavam como "indispensable que nos vengan algunos ministros de Europa"80. Se esta era a pretensão, não é de se surpreender que as declarações oficiais de igualdade ou reciprocidade na provisão de ofícios fossem contestadas como insuficientes ${ }^{81}$. A primeira e mais importante teve lugar em 1776, quando se decidiu - não é possivel determinar se em atenção à proposta que anos antes havia efetuado o Consejo extraordinario - elevar esse critério à regra geral para o provimento dos ofícios togados na Espanha e na América ${ }^{82}$. É difícil saber se chegou a permear em alguma medida a política de nomeações. Mesmo se se pretendeu impor efetivamente como regra a seguir - sobre o qual não é preciso ter muitas ilusões -, sua aplicação em cada caso a favor dos americanos teria que vencer o nepotismo dos conseIheiros da Câmara e ainda lutar contra a tendência que na hora de receber graças favorecia, de modo quase natural em uma monarquia absoluta, aos que, por estarem mais próximos do soberano, podiam pretender e insistir ou intrigar com maior facilidade. ${ }^{83}$ De qualquer maneira, não era isto o que ali se pedia e esperava. Desde antes a reivindicação das elites criollas era exercer a magistratura, não em qualquer outro lugar da América, mas em suas próprias cidades, tal como é manifesto nos protestos levantados no México e em Lima ao final do século, ligados já ao prelúdio dos movimentos de independência ${ }^{84}$.

A partir dos testemunhos citados, fala-se comumente, de modo geral e contundente, do descontentamento e da irritação ou do ressentimento dos criollos em relação à política de reformas, elevando-se a dicotomia peninsular-criollo à principal chave explicativa. ${ }^{85}$ Provavelmente, é o professor John Lynch o historiador que de modo mais brilhante expressou este difundido ponto de vista: haja vista que o reformismo bourbônico supôs a desconstrução do Estado criollo, rompeu o consenso colonial e abriu uma fase de absolutismo, que foi, ao fim e ao cabo, um fator destacado da independência. ${ }^{86}$

Como alguns têm assinalado, esta interpretação simplifica excessivamente a realidade das coisas e, segundo creio, não é inteiramente aplicável à administração da justiça. De pronto, supõe identificar o espírito criollo com os criollos; o discurso "essencialmente reivindicatório e exclusivista" elaborado por alguns com as expectativas e interesses de todos. ${ }^{87}$ Entendase bem: não se trata, como às vezes se tem feito, de julgar a sua veracidade, e menos ainda de justificar a política régia, mas de indagar até que ponto a dicotomia que está em sua base dá conta dos problemas da administração da justiça na América do Setecentos e dos intentos de solução ensaiados pelo "reformismo bourbônico", isso ao menos quando se trata de entender o seu sentido (e não de valorá-lo como um fator da independência, para a qual não duvido que o discurso criollo resultasse operativo). ${ }^{88}$ 
São estas: Ayuntamiento de México, 1792, que reproduz "casi con las mismas palabras su petición de 1771" (BURKHOLDER, Mark A. CHANDLER, Dewitt S. De la impotencia... Op. Cit., p.167); Colegio de Abogados de México, 1801, resumida na consulta do Consejo de Indias sobre o particular, de 7.V.1804 (apud KONETZKE, Richard. Colección de Documentos... Op. Cit., Vol. III-2, 363, p.799-807); Ayuntamiento de Lima, 1793 y 1799, nas Instrucciones a seu diputado Baquijano, para que ao menos a terceira parte da Audiencia se proveja precisamente em "Americanos peruanos", com expressa declaração de não haver impedimento para se servir na própria pátria (apud LOHMANN VILLENA, Guillermo. Op. Cit., p.xxix; BURKHOLDER, Mark A From Creole to Peninsular... Op. Cit., p.409-412; Idem, Politics, p. 93-99, BURKHOLDER, Mark A.; CHANDLER, Dewitt S. De la impotencia... Op. Cit. p.167-168); e novamente em suas Instrucciones ao diputado da Junta Central Silva y Olave (11.X.1809), resumidas por FISHER, John. The Intendant System and the Cabildos of Peru, 17841810. Hispanic American Historical Review, XLIX3, 1969, p.451-452 (assim como as referências anteriores). Para o periodo gaditano, ver: $W$. WOODROW ANDERSON. Reforms as a Means To Quell Revolution. In: BENSON, Nettie Lee (ed.). Mexico and the Spanish Cortes, 1810-1822: Eight Essays. Austin: University of Texas Press, 1966. p.188-189; y BURKHOLDER, Mark A.; CHANDLER, Dewitt S. De la impotencia... Op. Cit., p.192-199, para a política de nomeações neste periodo.

85

Assim, p.e., BURKHOLDER, Mark A.; CHANDLER, Dewitt S. De la impotencia... Op. Cit., p.162 ss., a quem pertencem as expressões citadas. LÓPEZ BOHÓRQUEZ qualifica taxativamente esta política como antiamericanista, operando assim uma espécie de sinédoque criollos-América (LÓPEZ BOHÓRQUEZ, Ali Enrique. Las reformas de Carlos III ... Op. Cit., p.335, p.337).

86

"La política de los últimos Borbones era aumenta el poder del Estado y aplicar a América un control imperial más estrecho, lo que constituía un retroceso con respecto a las tendencias anteriores y suspendía los logros ya obtenidos por los americanos. Así, a la era dorada de la América criolla, cuando las elites locales compraron su lugar en la Hacienda, la audiencia y otros cargos, y consiguieron un papel que parecia permanente en la administración, le siguió desde 1760 un nuevo orden, cuando el gobierno de Carlos III desmontó el Estado criollo y restauró la hegemonía española. Los cargos más elevados de las Audiencias, el ejército y la Hacienda se reservaron entonces casi en exclusiva para los peninsulares [...] Este modelo de crecimiento regional, autonomía de su elite e imperialismo renovado quizás proporcionó la primera prueba de la gran división de la historia colonial, la existente entre el Estado criollo y el Estado borbónico, entre compromiso y absolutismo, división que puede situarse en los años en torno a 1750" (GUIMERÁ, Agustin (ed.). El reformismo... Op. Cit., p.44-45).

87

Como escreveu Jacques LAFAYE: "el espíritu criollo ha precedido al nacimiento del primer criollo stricto sensu; luego, vinieron los españoles
Há de se descartar que a condição de natural tivesse nas Índias uma relevância jurídica imediata, pois nada indica que os votos dos magistrados dependessem do lugar de nascimento ${ }^{89}$, como podia ocorrer mais facilmente naqueles territórios que tinham uma tradição jurídica própria a defender. Uma vez mais, a comparação com a Audiencia catalã pode ser - desta vez a contrario - enriquecedora. Como sabido, após a Guerra da Sucessão e em virtude do Decreto de 1715, a Catalunha conservou a maior parte de seu direito próprio, que desde então teve de ser aplicado por um aparato institucional de nueva planta, cujo ápice era ocupado por uma Audiencia talhada a partir do padrão castelhano e presidida pelo Capitán General do Principado. Em tais circunstâncias, a condição nacional dos ministros tinha ou podia ter um significado primário da maior importância, que em seguida se traduziu em uma pugna mais ou menos inflamada entre ministros catalães e castelhanos, imprescindíveis aqueles para administrar a justiça conforme o direito e estilo de seu pais, baluarte estes - depois de uma guerra que a monarquia interpretava como traição - das regalias da Coroa. Precisamente por isso, a Cámara de Castela, segundo sua própria declaração (1730), havia "procedido siempre con reflexión a que siempre sea mayor el número de castellanos en cada sala que el de naturales, y los fiscales siempre castellanos" (assim como o regente, posso acrescentar). Se ainda for preciso explicar por que, o ponto de vista do presidente da Audiencia, em 1746, não deixava lugar para dúvidas: os ministros catalães "tratan y reciben [con repugnancia] cualquiera nueva providencia adictos siempre a su idolatrada antigüedad"90.

Não era este o caso das Índias, cuja única tradição própria (ou diferente), a indígena, não foi em absoluto considerada pelos juristas criollos. ${ }^{91}$ Aqui, lo que obra el amor a la pátria - conforme a formulação de Solórzano - concretizava-se na parcialidade que a solidariedade entre compatriotas podia causar, o que alguns admitiam como causa justa de recusa e era, de qualquer maneira, um argumento poderoso contra a provisão de ofícios a naturais da província, ao que, como foi visto, o discurso jurídico criollo aceitava. ${ }^{92}$ Sendo assim (e salvo que se queira admitir com caráter geral a paixão contra os estrangeiros por amor à pátria na hora de votar), considerar decisiva a divisão entre peninsulares e criollos exige contrapor os interesses materiais de uns e outros, supondo que os primeiros eram portadores per se de uma política que os segundos, também por essência, não estariam em condições de desenvolver, que são precisamente os termos nos quais - matizações à parte - parece situar-se a discussão historiográfica. Consequentemente, para avaliar a partir deste ponto de vista 0 impacto possível do reformismo bourbônico, é necessário indagar antes quem foram os seus beneficiários e os seus prejudicados.

Por um lado, é evidente que a restauração da política judicial da monarquia na segunda metade do século não afetou somente os criollos. Ao contrário: mesmo supondo um modo de "limitar la representación indirecta de la sociedad local en el gobierno", boa parte das medidas adotadas pre- 
"criollizados" llegados de la península, a menudo emparentados con familias criollas, que se identificaban espiritualmente con la sociedad criolla mexicana, abrazando las devociones locales y hasta su odio a los gachupines. Lo que definia al criollo, más que el lugar de su nacimiento, era el conocimiento del país y sobre todo la adhesión a una ética colonial de la sociedad". Cit. por Bernard LAVALLÉ. Del espíritu colonial a la reivindicación criolla, 1978, ahora en LAVALLÉ, Bernard. Las promesas... Op. Cit., p.23-43, esp. p.25.

88

Cf. LYNCH, John. El reformismo borbónico... Op. Cit., p.44-49.

89

Ver, p.e., os testemunhos que reúne CHANDLER, Dewitt S. Jacobo de Villaurrutia and the Audiencia of Guatemala, 1794-1804. The Americas, v.32, n.3, 1976, p.402-417.

90

Para tudo isto, remeto ao meu: Las Ordenanzas, onde está citada bibliografia pertinente. A opinião da Cámara está recolhida em: MOLAS RIBALTA, Pedro. Las Audiencias borbónicas de la Corona de Aragón (1976). In: Idem. Pedro et al. Historia social de la administración española. Estudios sobre los siglos XVII y XVIII. Barcelona: CSIC-Institución Milá y Fontanals, 1980, p.116164, esp. p.128 (e, em geral, sobre esta questão das "plazas nacionales", p.126-134; segundo seus dados, a média de oidores catalães ao longo do século XVIII foi de 32\%). A última frase é do marquês de Campofuerte, citada em: PÉREZ SAMPER, María Ángeles. La familia Alós. Una dinastía catalana al servicio del Estado (siglo XVIII). Cuadernos de Investigación Histórica, 6, 1982, p.195-239, esp. p.204.

91

A diferença dos cronistas e historiadores, como destacou especialmente BRADING, David. A. Orbe indiano.Contudo, e salvo isto, que é o principal, em 1771, o Ayuntamiento de México argumentou com inteligência para se opor ao "acomodo de los Europeos en los empleos publicos de las Indias": "Tienen estas, Leyes peculiares para su gobierno, Ordenanzas, Autos acordados, Cedulas Reales, estilos particulares de los Tribunales, y en una palabra un derecho entero, que necesita un estudio de por vida, y no lo ha tenido el Europeo; porque en su Patria le seria del todo infructuoso este trabajo" (p.433).

92

Cfr. supra nota 79. Veja-se SOLÓRZANO Y PEREYRA, Juan. Op. Cit.,lib.V, cap.IV, n.29-32, p.70-71; onde também trata sobre "si podrá ser recusado un Oidor en las Indias por sólo oponerse que es de la patria de alguno de los Litigantes, aunque no se pruebe otra correspondencia ni dependencia, porque parece que en partes remotas se aúnan siempre mucho los que son de una tierra y que asi eso basta para tenerlos por sospechosos". Cf. CARRASCO DEL SAZ, Interpretatio ad aliqvas leges, cap. IX, nº 119 ss. (f. 129rv).

93

A frase citada é de BURKHOLDER, Mark A.; CHANDLER, Dewitt S. De la impotencia... 0p. Cit., p.154. judicavam de modo direto a oidores peninsulares, que viam quando menos dificultadas suas eventuais expectativas de estabelecer laços proveitosos em seus distritos. ${ }^{93}$ Alguns autores tem falado a este respeito da rápida criollización dos oficiais peninsulares, para indicar a comunidade de interesses e a sujeição a padrões de comportamento semelhantes que geravam solidariedades entre os magistrados criollos. ${ }^{94}$ Afinal de contas, como escreveu $B$. Lavallé, "más allá de las apariencias, ser criollo, era un hecho que estaba más ligado a una forma de ser, a una adhesión a intereses locales, que al nacimiento en tierra americana"95. Não creio que no caso das Audiências se requeira, a esta altura, maior demonstração, mas me parece significativo que alguns dos principais discursos a favor da prioridade dos criollos no preenchimento de cargos tenham partido de peninsulares (como Carrasco del Saz ou o próprio Solórzano). Em termos puramente materiais, que são, devo insistir, aqueles nos quais parece se situar a discussão, o benefício derivava em ambos os casos do enraizamento e os prejuizos, por conseguinte, de todas as medidas que o impedissem ou dificultassem. Se evitá-lo era o principal objetivo da política judicial da monarquia, era porque na radicação estava a mais clara ameaça à reta administração da justiça. Ou dito em outros termos, que me parecem mais adequados à configuração própria da administração da justiça, a designação de oidores peninsulares não bastava para assegurar o domínio sobre os tribunais da América. Assim, para conhecer o impacto que tiveram as reformas bourbônicas nas Audiencias (e, por extensão, sobre as sociedades) americanas do Setecentos não importa tanto conhecer a proporção entre criollos e peninsulares no seio dos tribunais, mas, sim, indagar como e em que medida se conseguiu evitar a imbricação dos juizes na sociedade local. Não parece prudente ter muitas ilusões a respeito, tendo em conta a abundância de testemunhos em contrário. ${ }^{96}$ Nestas condições, sintetizar 0 reformismo bourbônico em termos como "centralização" resulta, no mínimo, inapropriado, como a seu tempo algunos coevos não deixaram de advertir.97 Ao final, se algo demonstra a experiência do reformismo bourbônico no âmbito da justiça é a impossibilidade de impor a vontade real ao aparato institutido para administrá-la. ${ }^{98}$

Por outro, nem todos os criollos (para não falar dos outros americanos) deveriam sentir-se igualmente prejudicados pela política judicial desenvolvida a partir de 1750. Me parece que, a esta altura, o leitor tem elementos suficientes para julgar. A mim, basta acrescentar às suas próprias reflexões que os mais claramente prejudicados foram os que levantaram ou impulsionaram os principais protestos, ou seja, aqueles que tinham expectativas razoáveis de obter cargos nas Audiencias. Ainda que isso seja o de menos, em termos globais (e, portanto, de modo insatisfatório para dissipar os descontentamentos individuais) os criollos obtiveram 30\% (62 de 201) dos cargos providos entre 1751 e 1808 . Mas muito mais significativo é recordar que houve outros setores sociais indianos que satisfizeram as suas expectativas de participar no governo de seus interesses, sem a necessidade de interver no aparato judicial: a restauração da justiça ordi- 
Assim, p. ex., nos trabalhos que Michel Bertrand vem dedicando aos oficiais de hacienda da Nova Espanha, em uma abordagem em que coincido amplamente: Comment peut-on être créole? Sur les relations sociales en Nouvelle-Espagne au XVIIIe siècle. Caravelle. Cahiers du monde hispanique et Iuso-brésilien, n.62, 1994, p.99-109; Idem. Du bon usage des solidarités. Ëtude du facteur familial dans l'administration des Finances de Nouvelle-Espagne, XVIle-XVIIle siècle. In: DESCIMON, Robert; SCHAUB, Jean-Frédéric; VINCENT. Bernard. (dirs.). Les figures de l'administrateur. Institutions, réseaux, pouvoirs en Espagne, en France et au Portugal, 16e-19e siècle. Paris: Éditions de l'École des Hautes Études en Sciences Sociales, 1997, p.43-58, esp. p.50-52 y $\mathrm{p} .57-58$.

95

LAVALLÉ, Bernard. Del espiritu colonial... Op. Cit., p.25.

96

Podem encontrar-se alguns muito expressivos, p.ex., em DEUSTA PIMENTEL, C. Un informe secreto del Virrey Gil de Taboada sobre la Audiencia de Lima. Revista Histórica, XXI, Perú, 1954, p.274-287; CAMPBELL, Leon G. Op. Cit., p.16-20; BARBIER, Jacques $A$. Elite and Cadres in Bourbon Chile. HAHR, v.52, n.3, 1972, p.416-435; ALBORNOZ DE LÓPEZ, Teresa. Op. Cit.; LÓPEZ BOHÓRQUEZ, Alí Enrique. Los ministros... Op. Cit., p.esp. p.112 ss.

97

Assim, p.e., o conde de Aranda considerava como uma das principais dificuldades para manter as possessões americanas: "la distancia de la autoridad a la que [sus habitantes] tienen necesidad de recurrir para que se entiendan sus quejas, lo que hace que se pasen los años antes que se haga derecho a sus reclamaciones y las venganzas a que se quedan expuestos de parte de las autoridades locales en este intermedio, la dificultad de conocer bien la verdad a tanta distancia". Cit. por Miguel ARTOLA. América en el pensamiento español del siglo XVIII. Revista das Indias, v.XXIX, 115-118, 1969, p.51-77, esp. p.55. 98

Neste sentido, a propósito da hacienda BERTRAND, Michel. Comment peut-on être créole?... Op. Cit., p.109-110.

99

Consultei para isso e para o que segue: BRADING, David A. Mineros y comerciantes... Op. Cit., p.219-231 y p.435-448, onde está bem refletida a oposição da Audiencia; MARTIRÉ, Eduardo. Historia del derecho miner argentine. $2^{\text {a }}$ ed. Buenos Aires: Abeledo-Perrot, 1987. p.59-76; María del Refugio GONZÁLEZ, Estudio y edición. Ordenanzas de la Minería de la Nueva España formadas y propuestas por su Real Tribunal. México, UNAM, 1996, esp. 41-61, 75-84, 389-457.

100

México, 10.XI.1782: em sua opinião, "si las Audiencias no reasumen sus primitivas prerrogativas y superioridad, no tendrán todo el efecto deseado las clementes, sabias y magnánimas providencias de nuestro amado Soberano, en sus admirables reglamentos de justicia, aumento de Ministros y de sueldos". Apud BRADING, David A. Nuevo plan para la mejor administración de justicia en América. Boletín del nária ocorreu paralelamente ao desenvolvimento das jurisdições especiais, as quais, ao menos por vezes, foram configuradas pura e simplesmente como canais para a participação das elites criollas e como marco para o compromisso com os interesses locais. Provavelmente, o caso mais claro seja relacionado à mineração. Na Nova Espanha, durante o ministério de Gálvez, o ramo foi profundamente reformado, respondendo a petições e, em grande medida, concordando com as propostas dos próprios mineiros, concebidas e debatidas nos anos precedentes, e expostas em uma representación que a nombre de la Minería foi remetida ao rei no ano de $1774 .^{99}$ A história é muito conhecida. Para os nossos propósitos, basta recordar que, tal como proposto localmente, em 1776 foi organizado um grêmio mineiro e constituído um Tribunal central (1777), à semelhança dos Consulados de Comercio, o qual elaborou o projeto que derivaria, com escassas modificações, nas Ordenanzas de la Minería de Nueva España promulgadas em 1783. A partir de então, os organismos de governo da mineração, tanto os locais (Diputaciones) como o central (Tribunal), teriam, no grau correspondente a cada um deles, jurisdição privativa sobre os assuntos de minas, que passaram a estar alheios à Audiencia, a qual se opôs expressamente a todo momento e não deixou de manobrar o quanto pode para conservar a jurisdição sobre a matéria. Possivelmente, os exemplos poderiam multiplicar-se. Como dizia (e sentia) o regente da Audiencia do México em 1782, referindo-se a todas as congêneres:

conviene mucho restituírlas [a] su primitiva autoridad, que se ha disminuído notablemente con los fueros concedidos en todos los ramos de Real Hacienda, de Correos, Alcabalas, Tabacos, naipes, Pólvora y todas las Oficinas, Secretarias, y Tribunal de Cuentas, de manera que la jurisdicción ordinaria sólo la reconoce la menor parte del distinguido pueblo, y viene a quedar, sobre la ínfima, que también se va exceptuando con el establecimiento de Milicias. ${ }^{100}$

Se não estou equivocado, o compromisso foi um dos principais instrumentos da chamada "revolución en el gobierno" borbônica. Se por consenso colonial entendemos a relativa autonomia que, de facto, as elites disfrutaram para gerir os assuntos públicos locais, mediatizando o governo da justiça pela omissão (ou diante da impotência) da Coroa durante a primeira metade do XVIII, é evidente que ele, assim considerado, rompeu-se em meados do século. Mas isso não significa que a partir de então o compromisso tenha deixado de ser um método habitual de governo. ${ }^{101}$ Não sei se é muito exagerado dizer, empregando termos da historiografia que nos ocupa, que, contrariamente à aparência que busca fabricar o discurso oficial, um novo consenso colonial então substituiu o anterior ${ }^{102}$, aquele que teve de ser cancelado porque atentava contra os mesmos fundamentos da monarquia.

A administração da justiça tinha então as suas próprias regras, que eram irredutíveis a um mero conflito de interesses entre peninsulares e criollos, e que eles respeitaram pelos menos até bem adentrado o século XVIII. ${ }^{103}$ É verdade que a reivindicação de cargos foi um elemento cada 
Archivo General de la Nación, v.IX, n.3-4 1968, p.367-400, esp. p.378 y p.379.

101

Mesmo que sob outra perspectiva, interessa para isso a conclusão de FISHER, John. La rebelión de Túpac Amaru y el programa de la reforma imperial de Carlos III. AEA, XXVIII, 1971, p.405-421.

102

Ver a interessantíssima conclusão a qual, expressamente contra a interpretação habitual do "reformismo borbónico", chega PÉREZ HERRERO, Pedro, depois de analisar as cifras de ingressos e gastos da Real Hacienda da Nova Espanha: "la fuerza del gobierno metropolitano dependió en este periodo no tanto de su capacidad extractora de beneficios fiscales, sino más bien de la voluntad de las élites locales de donar recursos a cambio de protección económica y de la justificación política e ideológica de su estructura colonial. [...] si se dio un fortalecimiento de la estructura imperial, no fue tanto por la capacidad de control del gobierno metropolitano, cuanto por el compromiso de los grupos de poder indianos de mantener el statu quo" (Los beneficiarios del reformismo borbónico: metrópoli versus élites novohispanas. Historia Mexicana, v.XLI, n.2, 1991, p.207-264, esp. p.241; Idem. Reformismo borbónico y crecimiento económico. 0p. Cit., p.85-91.

\section{3}

Vide, supra, n.79. Regras conforme as quais "consenso colonial" era equivalente à parcialidade e "absolutismo" era condição necessária da "boa administração da justiça". Certamente, postos a enjuiciar a atitude da monarquia, esta bem pôde corrigir sua política de nomeações, designando um maior número de criollos fora dos seus lugares de nascimento, como reclamavam alguns, mas manter aquele "consenso" teria sido o mesmo que saltar sobre sua própria sombra.

104

Sobre o problema histórico em questão já chamou a atençao, a partir do contraste entre os interesses e a consciência criolla, JOHNSON, Lyman L. Recent Contributions to the History of Eighteenth-Century Spanish America. Latin American Research Review, v. XVII, n.2, p.222-230, 1982

105

A frase é de BURKHOLDER, Mark A.; CHANDLER, Dewitt S. De la impotencia... Op. Cit., p.191.

106

A conclusões similares, mas, a meu juizo, extremadas, chega Michel Bertrand, analisando a administração financeira: Du bon usage des solidarités... Op. Cit., p.57-58.

\section{7}

Basta recordar, simplesmente, a maneira como os pleitos eram sentenciados: SOLÓRZANO Y PEREYRA, Juan. Op. Cit.,lib.V, cap.VIII, n. 53-58, p.133-135; MARILUZ URQUIJO, José María. La acción de sentenciar a través de los apuntes de Benito de la Mata Linares. Revista de Historia del Derecho, n.4, 1976, p.141-159; TAU ANZOÁTEGUI, Victor, Op. Cit., p.481 ss.

108

Alguns exemplos podem ser encontrados em: BRADING, David A. Mineros y comerciantes... Op. Cit., p.323-329; DEANS-SMITH, Susan. vez mais importante no que, para abreviar, chamo discurso criollo, e não cabe dúvida que a seu tempo foi operativo como argumento a favor da independência; mas esta constatação deve ser encarada como um problema histórico a ser considerado para compreender a formação da consciência nacional e não tomada como uma solução historiográfica para explicar o governo da justiça (que é o que se faz quando se utilizam os argumentos evocados por uns e outros naquele processo para avaliar a política da monarquia). ${ }^{104}$

\section{(V)}

Absolutismo face ao compromisso? As considerações feitas até agora aconselham que o problema seja situado em outra dimensão, que me parece mais adequada à compreensão da administração da justiça nas Índias durante o século XVIII (e, por extensão, dado o seu caráter central, à explicação do reformismo bourbônico em seu conjunto), a saber: as possibilidades e os limites da Coroa para governar, e em particular para governar a justiça, que além disso se viam consideravelmente reduzidas (aquelas) e ampliados (estes) pelas circunstâncias peculiares (o oceano Atlântico não era a menor delas) dos territórios americanos. Vista em seu conjunto, a política da Coroa na segunda metade do século parece menos absolutista e mais conciliadora do que normalmente se diz, ainda que seja apenas porque os fins oficial e programaticamente declarados nem sempre eram alcançáveis com os meios institucionais disponíveis, que no caso da justiça estavam recobertos por um conjunto de regras que 0 rei não podia alterar nem sequer a preço de deixar de ser o que era. Com efeito, segundo creio, o conjunto de medidas que compõem isso que chamamos "reformismo bourbônico" revela, antes de tudo, a incapacidade da Coroa de controlar o governo político tal como estava configurado - o direito e os aparatos construídos para a sua aplicação - e denotan $a$ contrario que não se chegou a vislumbrar uma alternativa institucionalmente viável.

Ao menos aparentemente, desde meados do século a Coroa delimitou - sem eliminá-las - as influências locais no aparato judicial, de tal sorte que, nesta mesma medida, a política de reformas teve que facilitar que os magistrados fossem meios e não obstáculos para a realização da justiça. Mas isto de forma alguma significa que eles foram desde então "instrumentos para imponer la voluntad de España sin representar en lo más mínimo a los intereses locales"105: inclusive, se acaso este último fosse alcançado, não estaria garantido em absoluto conseguir o primeiro. ${ }^{106} \mathrm{Se}$ tal coisa é o que neste contexto se entende por absolutismo, ou o que pretende indicar-se com a expressão Edad del Poder, então deve-se dizer que a configuração tradicional da administração da justiça atua de imediato como um obstáculo institucional à sua implantação: a Coroa podia controlar a designação e o comportamento dos seus magistrados, e o fazia, mas ordinariamente não estava ao seu alcance a determinação das deci- 
Compromise and Conflict: the Tobacco Workers of Mexico City and the Colonial State, 1770-1810. Anuario de Estudios Americanos, v.XLIX, 1992, p.271-309, esp.296 ss. Sobre as características do aparato administrativo, aqui simplemente aludidas, remeto ao completo estudo de José María MARILUZ URQUIJO. El agente de la administración pública en Indias. Buenos Aires: Instituto Internacional de Historia del Derecho Indiano, 1998.

109

Para um resumo atualizado, ver: NAVARRO GARCÍA, Luis. Las reformas borbónicas en América. El Plan de Intendencias y su aplicación. Universidad de Sevilla, 1995.

110

Chamou a atenção sobre isto, para o caso mexicano: PIETSCHMANN, Horst. Dos documentos significativos para la historia del régimen de intendencias en la Nueva España. Boletín del Archivo General de la Nación, s.2, v.XII, n.3-4, México, 1971, p.397-442, reproduzindo testemunhos interessantíssimos a respeito; Idem. Las reformas borbónicas y el sistema de intendencias en la Nueva España. Un estudio político administrativo (1972). Trad. de R. R. Meyer Misteli. México: FCE, 1996. p.118-299; Idem. Consideraciones en torno a protoliberalismo, reformas borbónicas y revolución. La Nueva España en el último tercio del siglo XVIII. In: SARABIA VIEJO, ${ }^{\text {a }}$ Justina (coord.). Europa e Iberoamérica, cinco siglos de intercambios. Actas (=IX Congreso Internacional de Historia de América). Sevilla: Junta de Andalucia, 1992, III, p.325-350. A expressão que figura citada no texto é de Ernst HINRICHS. Giustizia contro amministrazione. Aspetti del conflitto politico interno al sistema nella crisi dell'ancien régime. In: CAPRA. Carlo. (ed.). La società francese dall'ancien régime alla Rivoluzione. Bolonia: Il Mulino, 1986. p.199-227.

111

Tomo a expressão dos Discursos críticos de J. F. de Castro (1765): cf. SCHOLZ, JohannesMichael. De camino hacia el templo de la verdad. La crítica de la justicia en el siglo XVIII español. In: Mayans y la llustración. Simposio Internacional en el Bicentenario de la muerte de Gregorio Mayans. Valencia: Publicaciones del Ayuntamiento de Oliva, 1981, II, p.573-609, esp.590-591. Para tudo isso, é fundamental a obra de TAU ANZOÁTEGUI, Víctor. Op. Cit., da qual interessam agora, especialmente, suas p. 141-227, p.315-425 y p.481-563. Para o argumento de fundo, ver: RIENZO, Eugenio di. Illuminismo politico? Alcuni problemi di metodo sulla storiografia politica del Settecento. Studi Storici, v.36, n.4, 1995, p.977-1010.

112

GARRIGA, Carlos; LORENTE, Marta. El juez y la ley... Op. Cit., p.113-142; Idem. El modelo constitucional gaditano. In: ROMANO, Andrea, a cura di, I/ modello costituzionale inglese e la sua recezione nell'area mediterranea tra la fine del 700 e la prima metà dell'800 (=Atti del Seminario internazionale di studi in memoria di Francisco Tomás y Valiente. Milano: Giuffrè, 1998. p.587-613. sões colegiadamente adotadas nos tribunais. ${ }^{107}$ Sem necessidade de entrar em maiores considerações que as expostas, assim o demonstra a experiência do reformismo bourbônico em sua vertente mais inovadora: o governo econômico, ativado precisamente para facilitar uma administração mais "executiva" do que a permitida pelos meios tradicionais.

Simplificando muitíssimo as coisas, poder-se-ia dizer que a tarefa do reformismo bourbônico consistiu em reduzir o espaço materialmente ocupado pela justiça e, portanto, inevitavelmente mediatizado por seus aparatos, para construir, sobre a base material deste modo "liberada" e cada vez mais acrescida de novas atribuições, outro aparato. Aparato esse - cujo eixo era o intendente - servido por "homens novos" - em sua maioria militares (e não letrados) - e capacitado para governar com critérios (administrativos e não judiciais) distintos dos tradicionais, que desde logo facilitavam o governo por compromisso, o consenso com os interesses locais, sem arranhar a consciência católica do soberano. ${ }^{108}$ Enfim, como é sabido, assim havia ocorrido nos reinos peninsulares, e assim terminou também ocorrendo nos indianos durante o último quarto do século. ${ }^{109}$ Frente à monarquia judicial desponta uma monarquia administrativa que resume em suas vicissitudes a chamada dinâmica estatal do Setecentos e, desde logo, explica o "conflito político interno ao sistema" característico do Despotismo llustrado em todos os lugares. Um conflito que se fazia visivel cotidianamente na multidão dos que concretamente enfrentavam as velhas magistraturas (encasteladas em seus procedimentos judiciais) com as novas autoridades (armadas de potestades econômicas, mais expeditas), parece que ao cabo com vantagem para as primeiras, o que não deixa de ser interessante para o nosso argumento. ${ }^{110}$

E é que - reforma como restauração, digo - se no âmbito da justiça nada substancial foi mudado, isso se deveu, antes de mais nada, ao fato de que não se concebia nenhuma alternativa ao modelo judicial tradicional, nenhum outro modo de administrar a justiça. É verdade que, ao final do período, constata-se claros sintomas de que o paradigma da justiça fissurava-se em termos discursivos ante os embates de uma nova concepção da "lei"; mas não chega a ser formulado um modelo institucional alternativo, isto é, não se concebe, de modo operacional, quais critérios devem substituir os vigentes na tarefa de construir um novo aparato judicial, em que os juizes fossem simplesmente a "boca das leis"111. Havia nisto algo mais do que medo da Revolução. Não haveria outro modo de se explicar que a revolução constitucional iniciada na Espanha em 1810 mantivesse uma notável continuidade institucional: ao menos aparentemente, circulam novas ideias acerca da justiça e de suas condições de realização, mas o modelo judicial do Antigo Regime permanece, apenas retocado em aspectos assessórios, os puramente organizativos. ${ }^{112}$

Esta foi a base a partir da qual foi enfrentada a tarefa de construção dos direitos nacionais nos distintos paises da América independente. Ao menos no México, o modelo de justiça legado pela Espanha foi assumido 
113

GARRIGA, Carlos. La recusación judicial... Op. Cit., p.221-239; LORENTE, Marta. Las resistencias a la ley en el primer constitucionalismo mexicano. In: La supervivencia del derecho español... Op. Cit., p.299-327.

114

E por isso as obras do século XVIII continuaram sendo editadas sem mais modificações que as necessárias para adaptá-las às mudanças legislativas que cada Estado foi introduzindo: GONZÁLEZ, Maria del Refugio. El derecho civil en México, 1821-1871. (Apuntes para su estudio). México: UNAM, 1988. É muito interessante para isso o trabalho de MAYAGOITIA, Alejandro. Ética profesional y protección jurídica de las personas: el derecho intermedio a través del Febrero Novísimo. Anuario Mexicano de Historia del Derecho, n.Vl, 1994, p.159-185. como próprio, sem outra alteração substantiva que a abolição dos elementos mais abertamente incompatíveis com a nova situação política, o mais significativo dos quais, como é fácil supor, afetava a condição dos magistrados. Como consequência direta disso, a imparcialidade dos juízes se converteu no problema principal, o qual se tentou resolver - isto é importante - mediante os critérios tradicionalmente aplicados ao governo da justiça, que eram os únicos disponiveis, como fica manifesto no extraordinário desenvolvimento experimentado pela recusação e pela responsabilidade judicial nas décadas que se seguiram à independência. Assim, se não estou equivocado e na medida em que a experiência mexicana possa ser generalizada, os novos regimes políticos da América herdaram não só os problemas, como também as soluções concebidas no Antigo Regime para administrar a justiça. ${ }^{113}$ Os limites políticos do reformismo bourbônico desapareceram junto com a monarquia católica, mas as suas possibilidades de realizar uma boa (ou exata) administração da justiça continuaram orientando o modelo judicial até boa parte do século XIX. Entretanto, ainda que privado dos seus fundamentos últimos e talvez mais soterrado do que nunca o paradigma (digamos católico) da justiça permaneceu alojado na consciência (ou no subconsciente) dos juristas. ${ }^{114}$ 